\title{
Trichlorostannyl complexes of Ruthenium(II): Synthesis, structure, reactivity and computational studies
}

\author{
Nuria Álvarez-Pazos a , Gabriele Albertin ${ }^{\text {b }}$, Stefano Antoniutti ${ }^{\text {, }}$, Jorge Bravo ${ }^{\text {a }}$, \\ Soledad García-Fontán ${ }^{\text {a, * }}$, J.M. Hermida-Ramón ${ }^{\text {c }}$, Gianluigi Zanardo ${ }^{\text {b }}$ \\ a Departamento de Química Inorgánica, Universidade de Vigo, Campus Universitario, E-36310, Vigo, Spain \\ ' Dipartimento di Scienze Molecolari e Nanosistemi, Università Ca' Foscari Venezia, Via Torino 155, 30172, Mestre Venezia, Italy \\ c Departamento de Química Física, Universidade de Vigo, Campus Universitario, E-36310, Vigo, Spain
}

\section{A R T I C L E I N F O}

\section{Article history:}

Received 22 March 2018

Received in revised form

20 August 2018

Accepted 21 August 2018

Available online 23 August 2018

\section{Keywords:}

Ruthenium complexes

Trichlorostannyl ligand

Diphosphinite ligand

DFT

NBO

\begin{abstract}
A B S T R A C T
Trichlorostannyl complexes $\left[\mathrm{Ru}\left(\mathrm{SnCl}_{3}\right)\left(\mathrm{Cp}^{\prime}\right) \mathrm{L}\right](\mathbf{2 a}-\mathbf{c})$ were prepared by treatment of optically active halfsandwich chlorocomplexes [ $\left.\mathrm{RuCl}\left(\mathrm{Cp}^{\prime}\right) \mathrm{L}\right](\mathbf{1 a}-\mathbf{c})$ with an excess of $\mathrm{SnCl}_{2} \cdot 2 \mathrm{H}_{2} \mathrm{O}$ in ethanol. Treatment of trichlorostannyl complexes $2 \mathbf{2 a}-\mathbf{c}$ with $\mathrm{NaBH}_{4}$ afforded trihydridostannyl derivatives $\left[\mathrm{Ru}\left(\mathrm{SnH}_{3}\right)\left(\mathrm{Cp}^{\prime}\right) \mathrm{L}\right]$ (3a-c) in moderated yields. Treatment of $\mathbf{2 a - c}$ with MgBrMe gave the trimethylstannyl complexes $\mathrm{Ru}\left(\mathrm{SnMe}_{3}\right)\left(\mathrm{Cp}^{\prime}\right) \mathrm{L}(\mathbf{4 a - c})$. Alkynylstannyl derivatives $\left[\mathrm{Ru}\left\{\mathrm{Sn}(\mathrm{C} \equiv \mathrm{CPh})_{3}\right\}\left(\mathrm{Cp}^{\prime}\right) \mathrm{L}\right](\mathbf{5 a}-\mathbf{c})$ were prepared by treatment of trichlorostannyl compounds 2a-c with an excess of $\mathrm{LiC} \equiv \mathrm{CPh}$ in thf. All the complexes present optical activity. The complexes were characterized spectroscopically and by X-ray crystal structure determination of $\left[\mathrm{RuCl}\left(\eta^{5}-\mathrm{C}_{5} \mathrm{Me}_{5}\right) \mathrm{L}\right](\mathbf{1 b}),\left[\mathrm{Ru}\left(\mathrm{SnCl}_{3}\right)\left(\eta^{5}-\mathrm{C}_{5} \mathrm{Me}_{5}\right) \mathrm{L}\right](\mathbf{2 b})$, and $\left[\mathrm{Ru}\left(\mathrm{SnCl}_{3}\right)\left(\eta^{5}-\right.\right.$ $\left.\left.\mathrm{C}_{9} \mathrm{H}_{7}\right) \mathrm{L}\right](\mathbf{2 c})$. The influence of different ligands on the $\mathrm{Ru}-\mathrm{P}$ interaction in several complexes 1a-c, 2a-c and 3a-c was evaluated by DFT calculations. These calculations indicate that $\left[\mathrm{SnCl}_{3}\right]^{-}$has a stronger stabilization effect than $[\mathrm{Cl}]^{-}$and the same occurs between $-\mathrm{C}_{9} \mathrm{H}_{7}$ and $-\mathrm{C}_{5} \mathrm{Me}_{5}$. These relative stabilities combined with the distortion energies of the fragments produce a stabilizing effect in the Ru-P bonds of complex $\mathbf{2 c}$ that is twice as strong as in the $\mathbf{1 b}$ complex.
\end{abstract}

() 2018 Elsevier B.V. All rights reserved.

\section{Introduction}

Although transition-metal complexes containing stannyl ligands have been known for a long time [1], a renewed interest has been growing in the recent decades [2] even extending to the actinides [3]. It is known that the introduction of a stannyl ligand may improve the catalytic properties of metal complexes [4]. Compounds containing trihalogen $\left(\mathrm{SnX}_{3}\right)$ offer the possibility of substituting the halogen $(\mathrm{X})$ by $\mathrm{H}, \mathrm{OH}$, alkyl, ...thus allowing us to obtain new ligands that can further modify the properties of the complexes. When the transition metal complexes display optical activity, their potential use in enantioselective catalysis poses an added value to the study of these compounds. Here we report the results of the studies on the synthesis, characterization and reactivity of chiral chloro-, and trichlorostannyl complexes of ruthenium stabilized by the half-sandwich fragments $\eta^{5}-\mathrm{C}_{5} \mathrm{H}_{5}, \eta^{5}$ $\mathrm{C}_{5} \mathrm{Me}_{5}$, and $\eta^{5}-\mathrm{C}_{9} \mathrm{H}_{7}$. In addition, the reactivity of the

\footnotetext{
* Corresponding author.

E-mail address: sgarcia@uvigo.es (S. García-Fontán).
}

trichlorostannyl compounds with $\mathrm{NaBH}_{4}$, methylmagnesium bromide and lithium phenylacetylide is also reported. The chiral environment was achieved using the auxiliary chiral diphosphinite ligand 1,2-[bis(diphenyl)phosphanyloxy]-1,2-diphenylethane (L) to complete the coordination sphere around the ruthenium atom. Metal complexes bearing chiral diphosphinite ligands have proved to be active in asymmetric catalysis [5]. Vicinal diphosphinites deserve special attention because of the similarities of their coordination to a metal center with the efficient DIOP ligand [6] We also report computational studies of the $\left[\mathrm{RuX}\left(\mathrm{Cp}^{\prime}\right) \mathrm{L}\right] \mathrm{X}=\mathrm{Cl}, \mathrm{SnCl}_{3}, \mathrm{SnH}_{3}$; $\mathrm{Cp}^{\prime}=\eta^{5}-\mathrm{C}_{5} \mathrm{H}_{5}, \eta^{5}-\mathrm{C}_{5} \mathrm{Me}_{5}, \eta^{5}-\mathrm{C}_{9} \mathrm{H}_{7}$

\section{Results and discussion}

The reaction diphenylchlorophosphine with enantiomerically pure diol $(R, R)-(+)$-hydrobenzoine in the presence of ${ }^{n} \mathrm{BuLi}$, following procedure reported in the literature [7], led to formation of the optically active chelating ligand $(\mathrm{R}, \mathrm{R})-(+)-1,2-[$ bis(diphenyl) phosphanyloxy]-1,2-diphenylethane $(\mathbf{L})$ as a white solid. The compound can be stored under Ar at room temperature for four 


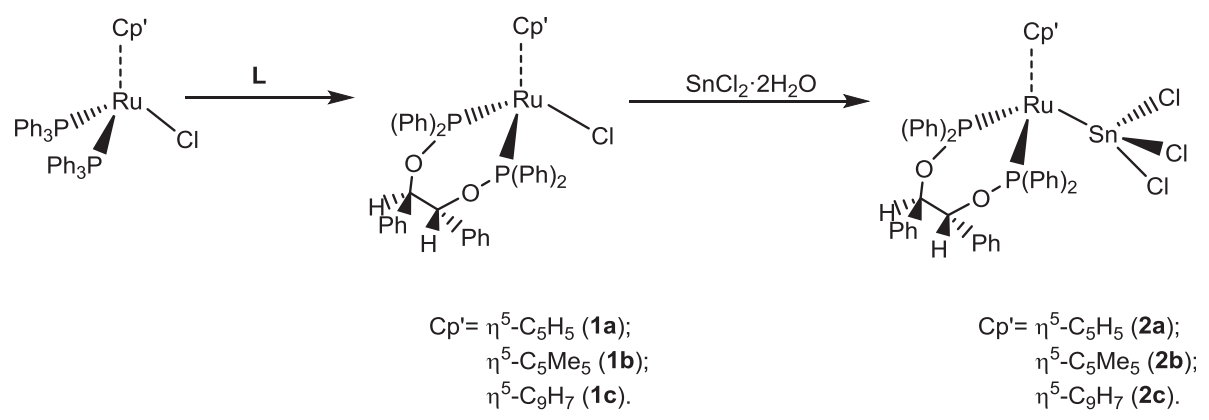

Scheme 1. Synthesis of the complexes $\left[\mathrm{RuCl}\left(\mathrm{Cp}^{\prime}\right) \mathrm{L}\right](\mathbf{1})$ and $\left[\mathrm{Ru}\left(\mathrm{SnCl}_{3}\right)\left(\mathrm{Cp}^{\prime}\right) \mathrm{L}\right](\mathbf{2})$.

weeks. After that its ${ }^{31} \mathrm{P}$ NMR spectrum shows small signals at $\delta \approx 20-40 \mathrm{ppm}$ corresponding to oxidation products.

The ${ }^{1} \mathrm{H}$ NMR spectrum in $\mathrm{CDCl}_{3}$ shows multiplets at 6.85-7.80 ppm, corresponding to the phenyl groups and a multiplet at $5.08 \mathrm{ppm}$ corresponding to the methylenic protons. The ${ }^{31} \mathrm{P}$ $\left\{{ }^{1} \mathrm{H}\right\}$ NMR spectrum shows a singlet at $109.7 \mathrm{ppm}$, indicating the magnetic equivalence of the two phosphorus nuclei of diphosphinite ligand.

Synthesis and characterization of the half-sandwich chloro- and trichlorostannylcomplexes $\left[\mathrm{RuCl}\left(\mathrm{Cp}^{\prime}\right) \mathrm{L}\right](1)$ and $\left[\mathrm{Ru}\left(\mathrm{SnCl}_{3}\right)\left(\mathrm{Cp}^{\prime}\right) \mathrm{L}\right]$ (2) $\mathrm{Cp}^{\prime}=\eta^{5}-\mathrm{C}_{5} \mathrm{H}_{5}(\mathrm{a}), \eta^{5}-\mathrm{C}_{5} \mathrm{Me}_{5}$ (b), $\eta^{5}-\mathrm{C}_{9} \mathrm{H}_{7}$ (c).

Optically active half-sandwich chlorocomplexes $\left[\mathrm{RuCl}\left(\mathrm{Cp}^{\prime}\right) \mathrm{L}\right]$ $\mathrm{Cp}^{\prime}=\eta^{5}-\mathrm{C}_{5} \mathrm{H}_{5}(\mathbf{1} \mathbf{a}), \eta^{5}-\mathrm{C}_{5} \mathrm{Me}_{5}(\mathbf{1 b}), \eta^{5}-\mathrm{C}_{9} \mathrm{H}_{7}(\mathbf{1 c})$, were prepared by thermal displacement of $\mathrm{PPh}_{3}$ from $\left[\left(\mathrm{RuCl}(\mathrm{Cp})\left(\mathrm{PPh}_{3}\right)_{2}\right]\right.$ complex by $\mathbf{L}$ in refluxing toluene, as shown in Scheme 1.

The new compounds are yellow 1a-b or red-orange 1c solids that are air-stable at room temperature and soluble in common organic solvents. Analytical and NMR spectroscopic data of compounds 1a-c support the proposed formulation. Thus, the phosphorus nuclei of the bidentate ligand $\mathbf{L}$ are inequivalent and hence a two-doublet pattern corresponding to an $\mathrm{AB}$ spin system is observed in the ${ }^{31} \mathrm{P}\left\{{ }^{1} \mathrm{H}\right\}$ NMR spectra. The ${ }^{1} \mathrm{H}$ NMR spectra display, in addition to the characteristic signals of the carbocyclic ligands, a collapsed doublet of doublets and a doublets of doublets corresponding to the diastereotopic methylene protons of $\mathrm{L}$ (see Experimental).

Insertion of $\mathrm{SnCl}_{2}$ into the $\mathrm{Ru}-\mathrm{Cl}$ bond of complexes 1a-c gave the trichlorostannyl complexes $\left[\mathrm{Ru}\left(\mathrm{SnCl}_{3}\right)\left(\mathrm{Cp}^{\prime}\right) \mathrm{L}\right] \quad(\mathbf{2 a - c})$ in moderate yields (50-58\%) (Scheme 1). The new stannyl complexes were isolated as air and moisture stable crystalline yellow (2a,b) or orange (2c) solids. Analytical and NMR spectroscopy data support this formulation. Therefore, the ${ }^{31} \mathrm{P}$ NMR spectra of $\mathbf{2 a - c}$ derivatives show two doublets (an AB system signal in the case of compound 2a) with the characteristic satellites, due to coupling with the ${ }^{119} \mathrm{Sn}$ and ${ }^{117} \mathrm{Sn}$ nuclei of $\mathrm{SnCl}_{3}$ ligand (Table 1). The ${ }^{119} \mathrm{Sn}$ NMR spectra also display a doublet of doublets (at $-36.7 \mathrm{ppm}$ for $\mathbf{2 c}$ ) or broad triplets (arising from the collapsed doublet of doublets with very similar coupling constants) at $-7.4 \mathrm{ppm}$ for $\mathbf{2 a}$ and at $-20.3 \mathrm{ppm}$ for $\mathbf{2 b}$. The comparison of the ${ }^{31}$ P NMR data of compounds $\mathbf{1}$ and $\mathbf{2}$ shows that the insertion of $\mathrm{SnCl}_{2}$ has little or no influence on one of the $\mathrm{P}$ nuclei but produces a low field displacement on the other. This dissimilar behavior has already been reported for other complexes. So, in the case of $\left[\mathrm{Ru}\left(\mathrm{C}_{5} \mathrm{H}_{5}\right) \mathrm{Cl}\right.$ (dippe)] and $\left[\mathrm{Ru}\left(\mathrm{C}_{5} \mathrm{Me}_{5}\right) \mathrm{Cl}\right.$ (dippe)] the insertion of $\mathrm{SnCl}_{2}$ does not affect the ${ }^{31} \mathrm{P}$ chemical shift [8c]; however for $\left[\mathrm{Ru}\left(\mathrm{C}_{5} \mathrm{H}_{5}\right) \mathrm{Cl}\right.$ (prophos)] [8f] and for $\left[\mathrm{Ru}\left(\mathrm{C}_{5} \mathrm{H}_{5}\right)\right.$ $\left.\mathrm{Cl}\left(\mathrm{PPh}_{3}\right)_{2}\right][8 \mathrm{~g}]$ high and low field displacements were respectively observed. As expected, compounds 2a-c present optical activity (see Experimental).

\subsection{X-ray structures of $1 b, 2 b$ and $2 c$}

The structure of compounds $\mathbf{1 b}, \mathbf{2} \mathbf{b}$ and $\mathbf{2 c}$ was determined by $\mathrm{X}$ ray diffraction studies. ORTEP drawings of these structures (Figs. 1-3) and selected bond lengths and angles (Table 2) are shown. The ruthenium atom is in a formally six-coordinate environment coordinated by the corresponding carbocyclic ligand, two

Table 1

${ }^{31} \mathrm{P}\left\{{ }^{1} \mathrm{H}\right\}$ and ${ }^{119} \mathrm{Sn}\left\{{ }^{1} \mathrm{H}\right\}$ NMR data for compounds $\mathbf{1}$ and $\mathbf{2}$.

\begin{tabular}{|c|c|c|}
\hline & ${ }^{31} \mathrm{P}\left\{{ }^{1} \mathrm{H}\right\} \mathrm{NMR}$ & ${ }^{119} \mathrm{Sn}\left\{{ }^{1} \mathrm{H}\right\}$ NMR \\
\hline Comp & $(\delta / \mathrm{ppm} ; \mathrm{J} / \mathrm{Hz})$ & $(\delta / \mathrm{ppm} ; \mathrm{J} / \mathrm{Hz})$ \\
\hline $1 \mathbf{a}$ & $\delta_{\mathrm{A}} 158.5, \delta_{\mathrm{B}} 153.1,{ }^{2} \mathrm{~J}_{\mathrm{AB}}=77.1$ & \\
\hline 1b & $\delta_{\mathrm{A}} 160.4, \delta_{\mathrm{B}} 156.6,{ }^{2} \mathrm{~J}_{\mathrm{AB}}=73.8$ & \\
\hline 1c & $\delta_{\mathrm{A}} 160.5, \delta_{\mathrm{B}} 157.5,{ }^{2} \mathrm{~J}_{\mathrm{AB}}=72.0$ & \\
\hline $2 a$ & $\begin{array}{l}\delta_{\mathrm{A}} 159.7 \\
{ }^{2} \mathrm{~J}^{31}-{ }_{\mathrm{p}}-{ }^{119} \mathrm{Sn} \\
\delta_{\mathrm{B}} 158.7468,{ }^{2} \mathrm{~J}^{31}{ }_{\mathrm{P}}-{ }^{117}{ }_{\mathrm{Sn}} \approx 448 \\
{ }^{2} \mathrm{~J}^{31}{ }_{\mathrm{P}}-{ }^{119} \mathrm{Sn} \\
{ }^{2} \mathrm{~J}_{\mathrm{AB}}=54.5\end{array}$ & $\begin{array}{l}-7.4 \mathrm{cdd}^{\mathrm{a}} \\
{ }^{2} \mathrm{~J}^{119} \mathrm{Sn}^{31}{ }_{\mathrm{P}}\end{array}$ \\
\hline 2b & 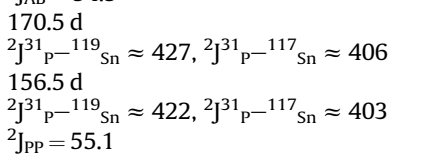 & $\begin{array}{l}-20.3 \mathrm{cdd}^{\mathrm{a}} \\
{ }^{2} \mathrm{~J}^{119} \mathrm{Sn}^{31}{ }_{\mathrm{P}} \approx 421\end{array}$ \\
\hline $2 c$ & $\begin{array}{l}163.6 \mathrm{~d} \\
{ }^{2} \mathrm{~J}^{31}{ }_{\mathrm{p}}-{ }^{119} \mathrm{Sn}=428.0,{ }^{2} \mathrm{~J}^{31}{ }_{\mathrm{P}}-{ }^{117} \mathrm{Sn}=416.3, \\
159.1 \mathrm{~d} \\
{ }^{2} \mathrm{~J}^{31}{ }_{\mathrm{p}}-{ }^{119} \mathrm{Sn}=363.1,{ }^{2} \mathrm{~J}^{31}{ }_{\mathrm{P}}-{ }^{117} \mathrm{Sn}=349.1 \\
{ }^{2} \mathrm{JPP}_{\mathrm{PP}}=50.8\end{array}$ & $\begin{array}{l}-36.7 \mathrm{dd}, \\
{ }^{2} \mathrm{~J}^{119}{ }_{\mathrm{Sn}}-{ }^{31}{ }_{\mathrm{P}}=430.8,{ }^{2} \mathrm{~J}^{119} \mathrm{Sn}^{3}-{ }_{\mathrm{P}}=365.2\end{array}$ \\
\hline
\end{tabular}

In $\mathrm{CD}_{2} \mathrm{Cl}_{2}$ at $25^{\circ} \mathrm{C}$. ${ }^{\text {a }}$ collapsed doublet of doublets. 


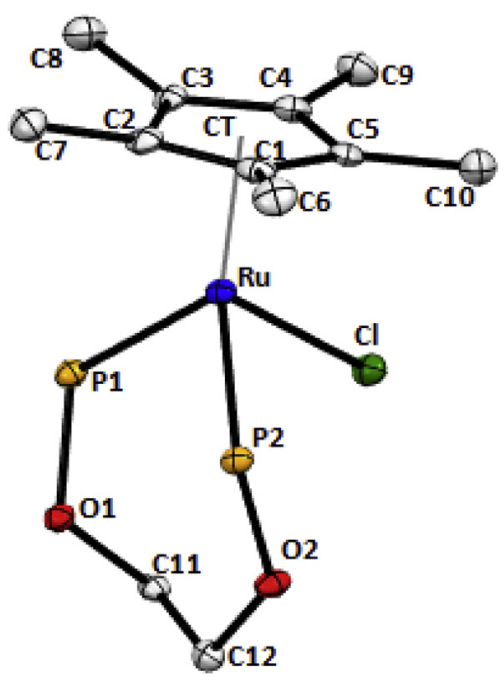

Fig. 1. ORTEP view (50\% probability level) of compound 1b. Hydrogen atoms and the phenyl groups are omitted for clarity.

phosphorous atoms from the bidentate ligand and a chloro (1b), or a trichlorostannyl $(\mathbf{2 b}, \mathbf{2 c})$ groups. All molecules have a "threelegged piano stool" geometry with values near $90^{\circ}$ for $\mathrm{P}(1)-\mathrm{Ru}-\mathrm{P}$ (2), P (1)-Ru-Sn and P (2)-Ru-Sn bond angles for compounds $\mathbf{2 b}$ and $2 \mathrm{c}$ and for $\mathrm{P}(1)-\mathrm{Ru}-\mathrm{P}(2), \mathrm{P}(1)-\mathrm{Ru}-\mathrm{Cl}$ and $\mathrm{P}(2)-\mathrm{Ru}-\mathrm{Cl}$ for 1b. The centroids of the carbocyclic ligands are situated at 1.884 (4) (1b) 1.905 (4) (2b) and 1.921 (2) $\AA$ (2c) from the ruthenium atom and the $\mathrm{Ru}-\mathrm{C}, \mathrm{Ru}-\mathrm{P}, \mathrm{Ru}-\mathrm{Cl}$ and $\mathrm{Ru}-\mathrm{Sn}$ bond lengths are similar to those observed for analog complexes [8]. It is worth mentioning that, in the case of compounds $\mathbf{1 b}$ and $\mathbf{2 b}$ both distances Ru-P (1) (2.242 $\AA$ (1b), $2.299 \AA(\mathbf{2 b}))$ and $\mathrm{Ru}-\mathrm{P}(2)(2.255 \AA$ (1b), $2.283 \AA$ (2b)) are almost identical, but for compound $2 \mathbf{c}$ they are significantly different (Ru-P (1) $2.283 \AA, \mathrm{Ru}-\mathrm{P}$ (2) $2.237 \AA$ ), probably due to steric effects attributed to the asymmetry of the indenyl ligand. In fact the non-bonding distance between the center of the sixmember ring of the indenyl group and $\mathrm{P}(1)(4.243 \AA)$ is significantly shorter than for P (2) (5.302 $\AA$ ) implying a stronger steric interaction of this group with the phenyl groups attached to the $\mathrm{P}$ (1) than with those attached to the $\mathrm{P}(2)$. The geometry around the center of Sn (II) is pyramidal trigonal with an average value for $\mathrm{Sn}-\mathrm{Cl}$ bond distance of $2.3963 \AA$ (2b) and $2.4045 \AA$ (2c) and an average $\mathrm{Cl}-\mathrm{Sn}-\mathrm{Cl}$ angle of $92.61^{\circ}(\mathbf{2 b})$ and $95.38^{\circ}(\mathbf{2 c})$. These values are similar to those found in the analogous compounds in the literature [ $2 \mathrm{~b}, 8 \mathrm{~g}]$.

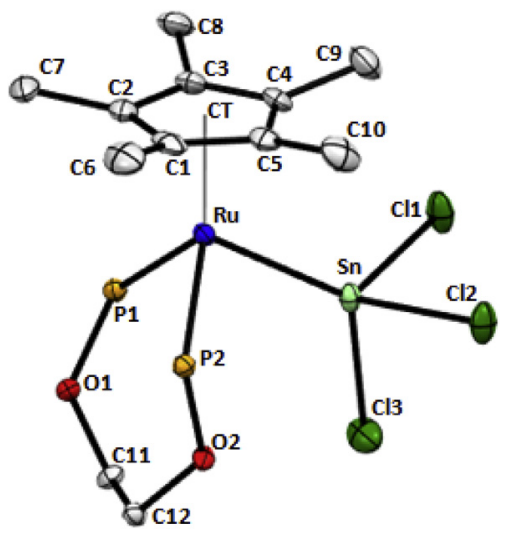

Fig. 2. ORTEP view (50\% probability level) of compounds $\mathbf{2 b}$. Hydrogen atoms and the phenyl groups are omitted for clarity.

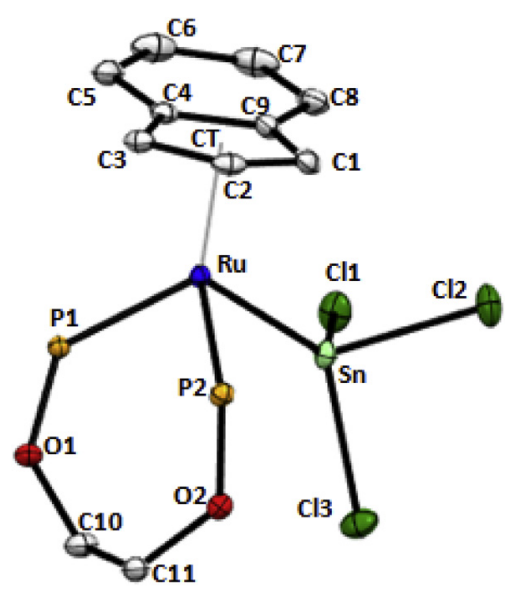

Fig. 3. ORTEP view (50\% probability level) of compounds $\mathbf{2 c}$. Hydrogen atoms and the phenyl groups are omitted for clarity.

\subsection{Reactivity of trichlorostannylcomplexes $2 a-c$}

Treatment of compounds $\left[\mathrm{Ru}\left(\mathrm{SnCl}_{3}\right)\left(\mathrm{Cp}^{\prime}\right) \mathrm{L}\right] \mathbf{2 a}$-c with $\mathrm{NaBH}_{4}$ in ethanol at room temperature permits substitution of the three chlorides in the $\mathrm{SnCl}_{3}$ group with $\mathrm{H}^{-}$, affording the trihydridostannyl derivatives $\left[\mathrm{Ru}\left(\mathrm{SnH}_{3}\right)\left(\mathrm{Cp}^{\prime}\right) \mathrm{L}\right]\left[\mathrm{Cp}^{\prime}=\eta^{5}-\mathrm{C}_{5} \mathrm{H}_{5}(\mathbf{3 a}), \eta^{5}\right.$ $\mathrm{C}_{5} \mathrm{Me}_{5}(\mathbf{3 b}), \eta^{5}-\mathrm{C}_{9} \mathrm{H}_{7}$ (3c)] in moderate yields (52-66\%). It is worthy to mention that these compounds, together with those published by the Albertin group, are the only transition metal trihydridostannyl complexes published to date [2 b,c,e,f]. The compounds are yellow, stable in air for a few days and unstable in solutions of halogenated solvents. The IR spectra show a medium intensity band at about $1700 \mathrm{~cm}^{-1}$ attributed to the $v_{\mathrm{Sn}-\mathrm{H}}$ of the trihydridostannyl ligand [2d]. The ${ }^{1} \mathrm{H}$ NMR spectra confirm the presence of the $\mathrm{SnH}_{3}$ ligand, showing a singlet at $4.28 \mathrm{ppm}$ (3a), $4.45 \mathrm{ppm}$ (3b), and $4.09 \mathrm{ppm}$ (3c), with the characteristic satellites due to coupling with ${ }^{119} \mathrm{Sn}$ and ${ }^{117} \mathrm{Sn}$ nuclei. The values of these coupling constants are similar to those observed for similar complexes [2b,d]. The ${ }^{31} \mathrm{P}$ NMR spectra of compounds 3a-c display signals corresponding to an $\mathrm{AB}$ spin system with the satellites due to coupling with the ${ }^{119} \mathrm{Sn}$ and ${ }^{117} \mathrm{Sn}$ nuclei of $\mathrm{SnH}_{3}$ ligand. It was not possible to record the ${ }^{119} \mathrm{Sn}$ NMR spectra of compounds 3a-c because of the aforementioned unstability of their solutions. Optical activity of these compounds is also observed.

Compounds $\left[\mathrm{Ru}\left(\mathrm{SnCl}_{3}\right)\left(\mathrm{Cp}^{\prime}\right) \mathrm{L}\right]$ 2a-c react with nucleophiles like methylmagnesium bromide and lithium phenylacetylide to give new chiral triorganostannyl derivatives (Scheme 2). The reactions proceeded with the substitution of all the chlorides in $\mathrm{SnCl}_{3}$. Thus, reaction of $\mathbf{2 a - c}$ with an excess of $\mathrm{MeMgBr}$ in diethyl ether at room temperature gave the trimethylstannyl compounds $\left[\mathrm{Ru}\left(\mathrm{SnMe}_{3}\right)\right.$ $\left.\left(\mathrm{Cp}^{\prime}\right) \mathrm{L}\right],\left[\mathrm{Cp}^{\prime}=\eta^{5}-\mathrm{C}_{5} \mathrm{H}_{5}(\mathbf{4 a}), \eta^{5}-\mathrm{C}_{5} \mathrm{Me}_{5}(\mathbf{4 b}), \eta^{5}-\mathrm{C}_{9} \mathrm{H}_{7}(\mathbf{4 c})\right]$ in moderate yields (52-65\%). On the other hand, treatment of compounds 2a-c with an excess of $\mathrm{LiC} \equiv \mathrm{CPh}$ gave the tris(phenylacetylenide) stannyl compounds $\left[\mathrm{Ru}\left\{\mathrm{Sn}(\mathrm{C} \equiv \mathrm{CPh})_{3}\right\}\left(\mathrm{Cp}^{\prime}\right) \mathrm{L}\right],\left[\mathrm{Cp}^{\prime}=\eta^{5}-\mathrm{C}_{5} \mathrm{H}_{5} \quad(\mathbf{5 a})\right.$, $\left.\eta^{5}-\mathrm{C}_{5} \mathrm{Me}_{5}(\mathbf{5 b}), \eta^{5}-\mathrm{C}_{9} \mathrm{H}_{7}(\mathbf{5 c})\right]$ in moderate yields $(60-70 \%)$. Compounds $\mathbf{4 a - c}$ and $\mathbf{5 a - c}$ were obtained as air-stable yellow solids and their formulation was supported by analytical and spectroscopic (IR and NMR) data. The ${ }^{1}$ H NMR spectra of compounds 4a-c display, in addition to the expected signals for the diphosphinite and carbocyclic ligands, a singlet at $0.63 \mathrm{ppm}$ (4a), $0.30 \mathrm{ppm}$ (4b), and $-0.09 \mathrm{ppm}(\mathbf{4 c})$, with the characteristic ${ }^{119} \mathrm{Sn}$ and ${ }^{117} \mathrm{Sn}$ satellites, integrating by nine protons, which can be attributed to the methyl groups bonded to $\mathrm{Sn}$ atom. The ${ }^{13} \mathrm{C}\left\{{ }^{1} \mathrm{H}\right\}$ NMR spectra show a singlet at $-1.4 \mathrm{ppm} \quad\left(\mathrm{J}^{13} \mathrm{C}^{1}{ }^{119} \mathrm{Sn}=80.6 \mathrm{~Hz}\right) \quad(\mathbf{4 a}), \quad 1.4 \mathrm{ppm}$ $\left(\mathrm{J}^{13} \mathrm{C}^{-119} \mathrm{Sn}=37.2 \mathrm{~Hz}\right)(\mathbf{4 b})$, and $-2.0 \mathrm{ppm}\left(\mathrm{J}^{13} \mathrm{C}^{-}{ }^{119} \mathrm{Sn}=91.1 \mathrm{~Hz}\right)(\mathbf{4 c})$, 
Table 2

Selected bond lengths $(\AA)$ and angles $\left(^{\circ}\right)$ for $\mathbf{1 b}, \mathbf{2 b}$ and $\mathbf{2 c}$.

\begin{tabular}{|c|c|c|c|c|c|}
\hline \multicolumn{2}{|l|}{$1 \mathrm{~b}$} & \multicolumn{2}{|l|}{$2 b$} & \multicolumn{2}{|l|}{$2 c$} \\
\hline $\mathrm{Ru}-\mathrm{P}(1)$ & $2.242(3)$ & $\mathrm{Ru}-\mathrm{P}(1)$ & $2.2990(11)$ & $\mathrm{Ru}-\mathrm{P}(1)$ & $2.2830(7)$ \\
\hline $\mathrm{Ru}-\mathrm{P}(2)$ & $2.255(3)$ & $\mathrm{Ru}-\mathrm{P}(2)$ & $2.2835(10)$ & $\mathrm{Ru}-\mathrm{P}(2)$ & $2.2378(7)$ \\
\hline $\mathrm{Ru}-\mathrm{C}(1)$ & $2.219(4)$ & $\mathrm{Ru}-\mathrm{C}(1)$ & $2.271(4)$ & $\mathrm{Ru}-\mathrm{C}(1)$ & $2.240(3)$ \\
\hline $\mathrm{Ru}-\mathrm{C}(2)$ & $2.277(4)$ & $\mathrm{Ru}-\mathrm{C}(2)$ & $2.269(4)$ & $\mathrm{Ru}-\mathrm{C}(2)$ & $2.215(3)$ \\
\hline $\mathrm{Ru}-\mathrm{C}(3)$ & $2.266(4)$ & $\mathrm{Ru}-\mathrm{C}(3)$ & $2.255(4)$ & $\mathrm{Ru}-\mathrm{C}(3)$ & $2.206(3)$ \\
\hline $\mathrm{Ru}-\mathrm{C}(4)$ & $2.235(4)$ & $\mathrm{Ru}-\mathrm{C}(4)$ & $2.265(4)$ & $\mathrm{Ru}-\mathrm{C}(4)$ & $2.349(3)$ \\
\hline $\mathrm{Ru}-\mathrm{C}(5)$ & $2.239(4)$ & $\mathrm{Ru}-\mathrm{C}(5)$ & $2.254(4)$ & $\mathrm{Ru}-\mathrm{C}(9)$ & $2.350(3)$ \\
\hline $\mathrm{Ru}-\mathrm{CT}$ & $1.884(4)$ & $\mathrm{Ru}-\mathrm{CT}$ & $1.905(4)$ & $\mathrm{Ru}-\mathrm{CT}$ & $1.921(2)$ \\
\hline \multirow[t]{4}{*}{$\mathrm{Ru}-\mathrm{Cl}$} & $2.433(3)$ & $\mathrm{Ru}-\mathrm{Sn}$ & $2.5655(4)$ & $\mathrm{Ru}-\mathrm{Sn}$ & $2.5871(3)$ \\
\hline & & $\mathrm{Sn}-\mathrm{Cl}(1)$ & $2.3991(11)$ & $\mathrm{Sn}-\mathrm{Cl}(1)$ & $2.4041(7)$ \\
\hline & & $\mathrm{Sn}-\mathrm{Cl}(2)$ & $2.3936(11)$ & $\mathrm{Sn}-\mathrm{Cl}(2)$ & $2.4003(7)$ \\
\hline & & $\mathrm{Sn}-\mathrm{Cl}(3)$ & $2.3963(12)$ & $\mathrm{Sn}-\mathrm{Cl}(3)$ & $2.4091(7)$ \\
\hline $\mathrm{CT}-\mathrm{Ru}-\mathrm{P}(1)$ & $129.68(6)$ & $\mathrm{CT}-\mathrm{Ru}-\mathrm{P}(1)$ & $128.4(2)$ & $\mathrm{CT}^{\prime}-\mathrm{Ru}-\mathrm{P}(1)$ & $127.22(2)$ \\
\hline $\mathrm{CT}-\mathrm{Ru}-\mathrm{P}(2)$ & $128.95(6)$ & $\mathrm{CT}-\mathrm{Ru}-\mathrm{P}(2)$ & $125.57(15)$ & $\mathrm{CT}^{\prime}-\mathrm{Ru}-\mathrm{P}(2)$ & $123.65(2)$ \\
\hline $\mathrm{P}(1)-\mathrm{Ru}-\mathrm{P}(2)$ & $88.75(7)$ & $\mathrm{P}(1)-\mathrm{Ru}-\mathrm{P}(2)$ & $90.04(4)$ & $\mathrm{P}(1)-\mathrm{Ru}-\mathrm{P}(2)$ & $90.93(2)$ \\
\hline $\mathrm{CT}-\mathrm{Ru}-\mathrm{Cl}$ & $116.87(14)$ & $\mathrm{CT}-\mathrm{Ru}-\mathrm{Sn}$ & $119.22(10)$ & $\mathrm{CT}^{\prime}-\mathrm{Ru}-\mathrm{Sn}$ & $114.818(10)$ \\
\hline $\mathrm{P}(1)-\mathrm{Ru}-\mathrm{Cl}$ & $92.67(7)$ & $P(1)-R u-S n$ & $92.84(3)$ & $P(1)-R u-S n$ & $100.73(2)$ \\
\hline \multirow[t]{4}{*}{$\mathrm{P}(2)-\mathrm{Ru}-\mathrm{Cl}$} & $88.24(5)$ & $P(2)-R u-S n$ & $90.49(3)$ & $P(2)-R u-S n$ & $91.83(2)$ \\
\hline & & $\mathrm{Cl}(3)-\mathrm{Sn}-\mathrm{Cl}(1)$ & $95.08(5)$ & $\mathrm{Cl}(3)-\mathrm{Sn}-\mathrm{Cl}(1)$ & $97.57(3)$ \\
\hline & & $\mathrm{Cl}(3)-\mathrm{Sn}-\mathrm{Cl}(2)$ & $93.32(4)$ & $\mathrm{Cl}(3)-\mathrm{Sn}-\mathrm{Cl}(2)$ & $92.50(3)$ \\
\hline & & $\mathrm{Cl}(2)-\mathrm{Sn}-\mathrm{Cl}(1)$ & $89.44(4)$ & $\mathrm{Cl}(2)-\mathrm{Sn}-\mathrm{Cl}(1)$ & $96.07(3)$ \\
\hline
\end{tabular}

CT: centroid at $\mathrm{Cp}^{*} ; \mathrm{CT}^{\prime}$ : centroid at the five-member ring of $\mathrm{C}_{9} \mathrm{H}_{7}$.

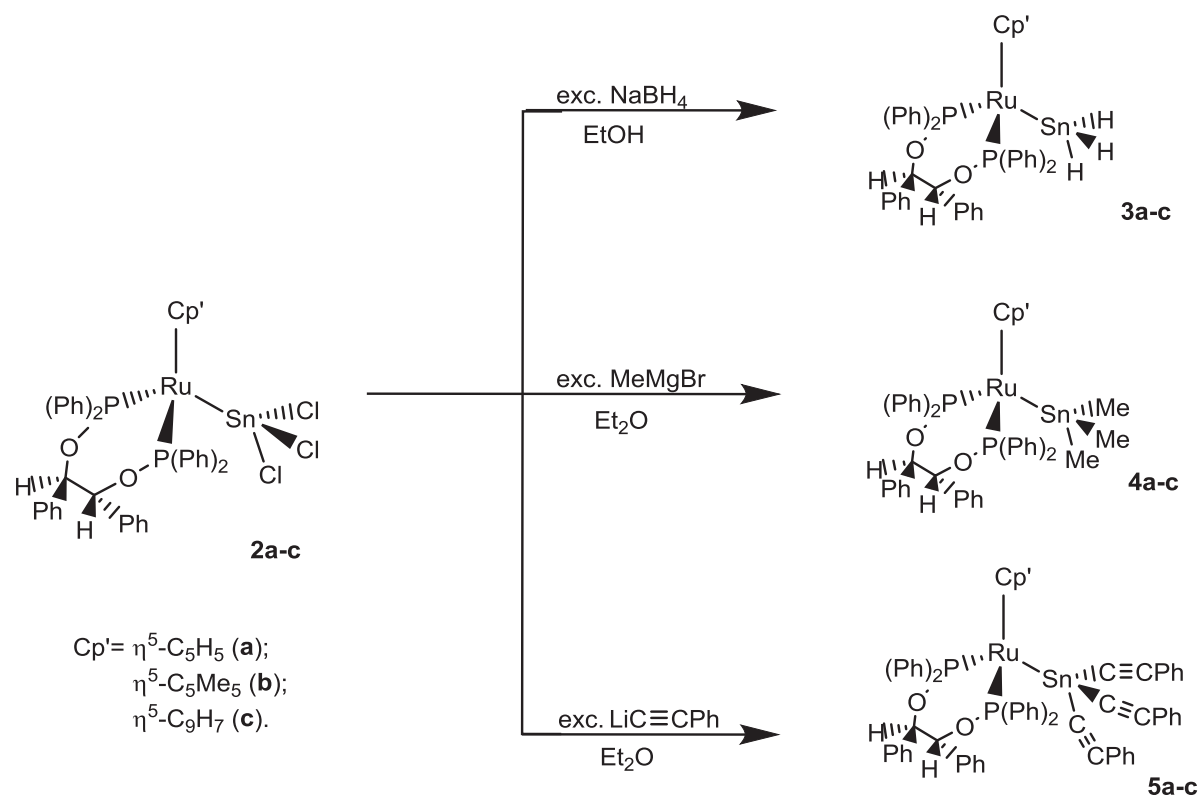

Scheme 2. Synthesis of the complexes $\left[\mathrm{Ru}\left(\mathrm{SnH}_{3}\right)\left(\mathrm{Cp}^{\prime}\right) \mathrm{L}\right](\mathbf{3})$; $\left[\mathrm{Ru}\left(\mathrm{SnMe}_{3}\right)(\mathrm{Cp}) \mathrm{L}\right](\mathbf{4}) ;\left[\mathrm{Ru}\left\{\mathrm{Sn}(\mathrm{C} \equiv \mathrm{CPh})_{3}\right\}\left(\mathrm{Cp}^{\prime}\right) \mathrm{L}\right](\mathbf{5})$.

correlating, in a HSQC experiment, with the corresponding, abovementioned, proton singlet. The proton-coupled ${ }^{119}$ Sn NMR spectrum of compound $\mathbf{4 c}$ shows a triplet of multiplets arising from the coupling with the two P nuclei of the bidentate ligand and the nine protons of the three methyl groups.

The IR spectra of compounds $\mathbf{5}$ present a medium-intensity broad band at $2124 \mathrm{~cm}^{-1}$ (5a) $2127 \mathrm{~cm}^{-1}$ (5b) and $2125 \mathrm{~cm}^{-1}$ (5c) that can be attributed to the $v_{\mathrm{C} \equiv \mathrm{C}}$ of the $\mathrm{Sn}(\mathrm{C} \equiv \mathrm{CPh})_{3}$ group [8]. Besides, the presence of the acetylide group bonded to the tin atom can be confirmed by the ${ }^{13} \mathrm{C}\left\{{ }^{1} \mathrm{H}\right\}$ and ${ }^{119} \mathrm{Sn}\left\{{ }^{1} \mathrm{H}\right\}$ NMR spectra. Thus, the ${ }^{13} \mathrm{C}\left\{{ }^{1} \mathrm{H}\right\}$ NMR spectra display, in addition to the characteristic signals of the supporting ligands, two singlets $[\delta=107.5$ and $\delta=100.7 \mathrm{ppm}(\mathbf{5 a}), \delta=107.2$ and $\delta=103.3 \mathrm{ppm}(\mathbf{5 b})$, and $\delta=107.2$ and $\delta=99.6(\mathbf{5 c})]$, attributed to $\mathrm{C}_{\beta}$ and $\mathrm{C}_{\alpha}$, respectively, of the $\operatorname{Sn}\left(C_{\alpha} \equiv C_{\beta} P h\right)_{3}$ group. The ${ }^{119} \operatorname{Sn}\left\{{ }^{1} H\right\}$ NMR spectra shows a collapsed doublet of doublets at $\delta=-248.5 \mathrm{ppm}$ (5a) and a doublet of doublets at $\delta=-233.2 \mathrm{ppm}(\mathbf{5 b})$ and at $\delta=-267.0 \mathrm{ppm}(\mathbf{5 c})$, due to the coupling of the tin nucleus with the two non-equivalent $P$ atoms of the chiral ligand.

${ }^{31} \mathrm{P}$ NMR data for compounds $\mathbf{3} \mathbf{- 5}$ are very similar suggesting that the modification of the groups attached to the Sn atom has little influence on the $\mathrm{P}$ atoms of the diphosphinite ligand.

Bimetallic compounds Ru-SnR $(R=H, M e, C \equiv C P h) \mathbf{3}-5$ are the first to contain a chiral phosphinite bidentate ligand.

\subsection{Computational studies}

Full optimizations at B3LYP/cc-pVDZ (-PP) [9] level of theory were performed in ground state for complexes 1a-c, 2a-c and 3a-c, for the phosphinite ligand ( $\mathbf{L}$ ) and for the moieties resulting from removing the phosphinite from the different complexes. Frequency and force constants were obtained at the same level of theory and 
the minimum nature of each geometry was established. Next, a natural bond orbital (NBO) analysis [10] was done together with obtaining the Wiberg bond indices (WBI) [11] and performing a natural population analysis (NPA) [12]. The most relevant distances of the studied compounds are listed in Table 3 along with the NPA charges, Wiberg bond indices, NBO populations and NBO energies.

The distances in Table 3 show that the $\eta^{5}-\mathrm{C}_{9} \mathrm{H}_{7}$ moiety breaks to a certain extent the equivalence of the two $\mathrm{Ru}-\mathrm{P}$ bonds in complexes 1c, 2c and 3c. This is confirmed by the Wiberg bond indices and the values of the NPA charges. In complexes with the $\eta^{5}-\mathrm{C}_{5} \mathrm{Me}_{5}$ or the $\eta^{5}-\mathrm{C}_{5} \mathrm{H}_{5}$ moiety the differences between the two phosphorus atoms are very small, suggesting a similar strength and nature of the two Ru-P interactions of each compound. The obtained value of the Wiberg bond indices for the Ru-P bonds goes from 0.79 to 0.90 , which points to a covalent nature of these bonds in all cases. The calculated NPA charges reveal that the Ru-P bonds are highly polarized for all complexes, with charges from $1.53 \mathrm{a}$. u. to $1.64 \mathrm{a}$. u. on the phosphorus atoms and from $-0.73 \mathrm{a}$. $\mathrm{u}$ to $-1.30 \mathrm{a}$. $\mathrm{u}$ on the ruthenium atom. The substitution of chloride by the $\mathrm{SnCl}_{3}$ or the $\mathrm{SnH}_{3}$ moieties increases the charge on the ruthenium atom in about $-0.4 \mathrm{a}$. u, which leads to a further polarization of the $\mathrm{Ru}-\mathrm{P}$ bonds. NBO isosurfaces displayed in the Supporting Information do not show significant differences in size or shape between the complexes. As can be seen in Table 3, the occupancy of all compounds is rather alike, but the combined effect of the chloride or of the $\mathrm{SnH}_{3}$ and $\eta^{5}-\mathrm{C}_{9} \mathrm{H}_{7}$ ligands breaks the equivalence of $\mathrm{Ru}-\mathrm{P}$ bonds in complexes 1c and 3c. These compounds have, in general, the bigger differences between $\mathrm{Ru}-\mathrm{P}$ bonds for all studied properties, i. e WBI, NPA charges, NBO populations and NBO energies. It is not clear if the asymmetry plays any role in it, but complex $1 \mathrm{c}$ has also the most stable Ru-P bonds according to the NBO energies.

By analyzing the distortion and the interaction energies in the complexes, we can perform an estimation of how the ligands modify the Ru-P interactions. In order to carry out this analysis a fragment-based approach is used in which a decomposition of the total energy of the complex $\left(\Delta \mathrm{E}_{\text {tot }}\right)$ is performed. This energy is divided in two terms, i.e. the interaction energy between two fragments $\left(\Delta \mathrm{E}_{\text {int }}\right)$ and the energy associated with distorting these fragments from their initial equilibrium structures $\left(\Delta \mathrm{E}_{\mathrm{dist}}\right)$. Thus, $\Delta \mathrm{E}_{\text {tot }}=\Delta \mathrm{E}_{\text {int }}+\Delta \mathrm{E}_{\text {dist }}$. The calculated results are given in Table 4 together with the Basis Set Superposition Error (BSSE) [13]. The fragments selected for our study were, on the one hand, the phosphinite ligand $(\mathbf{L})$ and on the other, the remaining $\left[\mathrm{RuCl}\left(\mathrm{Cp}^{\prime}\right)\right]$, $\left[\mathrm{Ru}\left(\mathrm{SnCl}_{3}\right)\left(\mathrm{Cp}^{\prime}\right)\right]$ and $\left[\mathrm{Ru}\left(\mathrm{SnH}_{3}\right)\left(\mathrm{Cp}^{\prime}\right)\right]$ for the complexes 1a-c, $\mathbf{2 a - c}$ and 3a-c, respectively. A further explanation of how those energies have been obtained is given in the Supporting Information.

The values of the interaction energy are very stabilizing, with energies of one $\mathrm{Ru}-\mathrm{P}$ interaction from about $-40 \mathrm{kcal} / \mathrm{mol}$ up to approximately $-55 \mathrm{kcal} / \mathrm{mol}$, considering that both Ru-P bonds of the same complex have roughly the same energy. Like in the NBO
Table 4

B3LYP/cc-pVDZ (-PP) distortion ( $\left.\Delta \mathrm{E}_{\text {dist }}\right)$, BSSE, interaction $\left(\Delta \mathrm{E}_{\text {int }}\right)$ and total $\left(\Delta \mathrm{E}_{\text {tot }}\right)$ energies $(\mathrm{kcal} / \mathrm{mol})$ computed for compounds $\mathbf{1}-\mathbf{3}$.

\begin{tabular}{lllllll}
\hline & $\boldsymbol{\Delta} \mathbf{E}_{\text {int }}$ & BSSE & $\boldsymbol{\Delta} \mathbf{E}_{\text {dist }}(\mathbf{L})$ & $\boldsymbol{\Delta} \mathbf{E}_{\text {dist }}[\mathbf{R u}(\mathbf{X})(\mathbf{C} \mathbf{p})]^{*}$ & $\boldsymbol{\Delta} \mathbf{E}_{\text {dist }}$ (total) & $\boldsymbol{\Delta} \mathbf{E}_{\text {tot }}$ \\
\hline $\mathbf{1 a}$ & -90.21 & 6.36 & 12.38 & 23.13 & 35.51 & -54.70 \\
$\mathbf{1 b}$ & -83.50 & 7.40 & 12.86 & 28.71 & 41.57 & -41.93 \\
$\mathbf{1 c}$ & -98.20 & 6.83 & 13.08 & 27.19 & 40.27 & -57.93 \\
$\mathbf{2 a}$ & -105.81 & 7.80 & 11.88 & 9.69 & 21.57 & -84.23 \\
$\mathbf{2 b}$ & -94.35 & 8.82 & 13.82 & 17.04 & 30.86 & -63.49 \\
$\mathbf{2 c}$ & -109.10 & 8.26 & 12.80 & 12.52 & 25.32 & -83.78 \\
$\mathbf{3 a}$ & -99.61 & 5.78 & 10.95 & 10.21 & 21.16 & -78.45 \\
$\mathbf{3 b}$ & -92.79 & 6.95 & 13.35 & 16.62 & 29.97 & -62.81 \\
$\mathbf{3 c}$ & -103.95 & 6.11 & 11.39 & 12.22 & 23.61 & -80.34 \\
\hline
\end{tabular}

$[\mathrm{Ru}(\mathrm{X})(\mathrm{Cp})]^{*} \mathrm{X}=\mathrm{Cl} ; \mathrm{SnCl}_{3} ; \mathrm{SnH}_{3}$.

analysis, the compound $\left[\mathrm{RuCl}\left(\eta^{5}-\mathrm{C}_{5} \mathrm{Me}_{5}\right) \mathrm{L}\right](\mathbf{1 b})$ has the less stable interactions. Yet, in contrast with NBO results the complex with the most stable interactions is the $\left[\mathrm{Ru}\left(\mathrm{SnCl}_{3}\right)\left(\eta^{5}-\mathrm{C}_{9} \mathrm{H}_{7}\right) \mathrm{L}\right](\mathbf{2 c})$. Differences in the BSSE values are not enough to produce any significant change in the relative stabilities between complexes. The values of $\Delta \mathrm{E}_{\text {dist }}$ are large, which reduces notably the stabilization of the complexes with respect to the interaction energies. The energy required for the geometrical distortion of $\mathbf{L}$ is rather similar for all complexes but large differences are found when the distortion energy of the $\left[\mathrm{RuCl}\left(\mathrm{Cp}^{\prime}\right)\right]$ or $\left[\mathrm{Ru}\left(\mathrm{SnCl}_{3}\right)\left(\mathrm{Cp}^{\prime}\right)\right]$ fragment is considered. Thus, this energy for $\left[\mathrm{RuCl}\left(\eta^{5}-\mathrm{C}_{5} \mathrm{Me}_{5}\right) \mathrm{L}\right](\mathbf{1 b})$ and $\left[\mathrm{RuCl}\left(\eta^{5}-\right.\right.$ $\left.\left.\mathrm{C}_{9} \mathrm{H}_{7}\right) \mathrm{L}\right](\mathbf{1 c})$ is almost three times as big as that for $\left[\mathrm{Ru}\left(\mathrm{SnCl}_{3}\right)\left(\eta^{5}-\right.\right.$ $\left.\left.\mathrm{C}_{5} \mathrm{H}_{5}\right) \mathrm{L}\right](\mathbf{2 a})$, which produces a much larger destabilization of the two former complexes. In $\left[\operatorname{RuCl}\left(\eta^{5}-\mathrm{C}_{5} \mathrm{Me}_{5}\right) \mathrm{L}\right](\mathbf{1 b})$, the large distortion energy of the $\left[\mathrm{RuCl}\left(\eta^{5}-\mathrm{C}_{5} \mathrm{Me}_{5}\right)\right]$ moiety is mainly due to the distortion of the $\mathrm{Ru}-\mathrm{Cl}$ bond. In the equilibrium geometry of the fragment, this bond is collinear with the axis defined by the apothem of the $\eta^{5}-C_{5} \mathrm{Me}_{5}$ and the ruthenium atom, but in the complex $\mathbf{1 b}$ it is placed forming an angle of around $61^{\circ}$ with this axis. This effect, combined with a rotation of the $\mathrm{Ru}-\mathrm{Cl}$ bond around the symmetry axis, is responsible for the large distortion energy in $\left[\mathrm{RuCl}\left(\eta^{5}-\mathrm{C}_{9} \mathrm{H}_{7}\right) \mathrm{L}\right](\mathbf{1 c})$.

When a comparison of the total energies is performed, we can establish the following correlation of ligands regarding the stability of the $\mathrm{Ru}-\mathrm{P}$ interactions, from less stable $\mathrm{Ru}-\mathrm{P}$ bonds to more stable bonds: $\eta^{5}-\mathrm{C}_{5} \mathrm{Me}_{5}<\eta^{5}-\mathrm{C}_{5} \mathrm{H}_{5} \approx \eta^{5}-\mathrm{C}_{9} \mathrm{H}_{7}$ and $[\mathrm{Cl}]^{-}$" $\left[\mathrm{SnH}_{3}\right]^{-}<\left[\mathrm{SnCl}_{3}\right]^{-}$. Thus, the relatively low stabilization of the $\mathrm{Ru}-\mathrm{P}$ interactions in the complex $\left[\mathrm{RuCl}\left(\eta^{5}-\mathrm{C}_{5} \mathrm{Me}_{5}\right) \mathrm{L}\right](\mathbf{1 b})$ is the combination of several effects: a1) the lower stabilization effect of the $\eta^{5}$ $\mathrm{C}_{5} \mathrm{Me}_{5}$ with respect to $\eta^{5}-\mathrm{C}_{9} \mathrm{H}_{7}$ and $\eta^{5}-\mathrm{C}_{5} \mathrm{H}_{5}$; a2) the lower stabilization effect of the chloride ligand with respect to the stannyl ligands; b1) the lower distortion energy of $\eta^{5}-\mathrm{C}_{9} \mathrm{H}_{7}$ and $\eta^{5}-\mathrm{C}_{5} \mathrm{H}_{5}$ regarding $\eta^{5}-\mathrm{C}_{5} \mathrm{Me}_{5}$; b2) the lower distortion energy of the stannyl ligands regarding the chloride ligand. The energy results suggest that less polarized $\mathrm{Ru}-\mathrm{P}$ bonds together with large distortions will

Table 3

Selected bond lengths (Angstroms), Wiberg bond indices, NPA atomic charges (atomic units) and NBO energies (eV) and populations (atomic units) for compounds 1-3.

\begin{tabular}{|c|c|c|c|c|c|c|c|c|c|}
\hline & $1 a$ & $1 \mathrm{~b}$ & $1 \mathrm{c}$ & $2 a$ & $2 \mathrm{~b}$ & $2 c$ & $3 a$ & $3 \mathrm{~b}$ & $3 c$ \\
\hline $\mathbf{r}_{\mathrm{Ru}-\mathrm{P} 1}$ & 2.300 & 2.323 & 2.269 & 2.326 & 2.363 & 2.299 & 2.286 & 2.310 & 2.267 \\
\hline $\mathbf{r}_{\mathrm{Ru}-\mathrm{P} 2}$ & 2.309 & 2.341 & 2.314 & 2.329 & 2.372 & 2.343 & 2.288 & 2.313 & 2.300 \\
\hline $\mathbf{W B I}_{\mathrm{Ru}}-\mathrm{P} 1$ & 0.86 & 0.82 & 0.89 & 0.84 & 0.79 & 0.86 & 0.89 & 0.85 & 0.90 \\
\hline $\mathbf{W B I}_{\mathrm{Ru}}-\mathrm{P} 2$ & 0.85 & 0.81 & 0.82 & 0.84 & 0.79 & 0.80 & 0.88 & 0.85 & 0.84 \\
\hline $\mathbf{q}_{\mathrm{Ru}}$ & -0.84 & -0.73 & -0.74 & -1.30 & -1.16 & -1.15 & -1.27 & -1.14 & -1.11 \\
\hline $\mathbf{q}_{\mathrm{P} 1}$ & 1.60 & 1.55 & 1.64 & 1.59 & 1.54 & 1.62 & 1.60 & 1.55 & 1.62 \\
\hline $\mathbf{q}_{\mathrm{P} 2}$ & 1.61 & 1.56 & 1.56 & 1.60 & 1.53 & 1.55 & 1.60 & 1.55 & 1.56 \\
\hline $\mathbf{E}_{\mathrm{Ru}-\mathrm{P} 1}$ & -12.72 & -12.06 & -13.52 & -13.05 & -12.70 & -12.21 & -12.13 & -12.78 & -12.00 \\
\hline $\mathbf{E}_{\mathrm{Ru}-\mathrm{P} 2}$ & -12.36 & -12.40 & -13.00 & -12.86 & -12.77 & -12.33 & -12.92 & -12.55 & -13.03 \\
\hline Pop $_{\mathrm{Ru}-\mathrm{P} 1}$ & 1.92 & 1.89 & 1.93 & 1.92 & 1.92 & 1.90 & 1.85 & 1.92 & 1.90 \\
\hline Pop $_{\text {Ru-P2 }}$ & 1.92 & 1.92 & 1.84 & 1.92 & 1.92 & 1.88 & 1.82 & 1.92 & 1.84 \\
\hline
\end{tabular}


produce lower stabilizations. As has also been pointed out above, the inclusion of the BSSE in the total energies will not change the outcome of the discussion.

\section{Conclusions}

In this work, we reported that cyclopentadienyl, pentamethylcyclopentadienyl and indenyl ligands in fragment [RuCp'L] ( $\mathrm{L}=$ phosphinite) can stabilize trichlorostannyl ([Ru]-SnCl 3 ), trihydridostannyl ([Ru] $\left.-\mathrm{SnH}_{3}\right)$ and organostannyl derivatives ([Ru]$\left.\mathrm{SnMe}_{3}\right)$ and $\left([\mathrm{Ru}]-\mathrm{Sn}(\mathrm{C} \equiv \mathrm{CPh})_{3}\right)$.

The calculated NPA charges reveal highly polarized $\mathrm{Ru}-\mathrm{P}$ bonds. The substitution of the chlorine by a $\left[\mathrm{SnCl}_{3}\right]^{-}$or a $\left[\mathrm{SnH}_{3}\right]^{-}$moiety increases the negative charge on the ruthenium atom. The influence of the ligands on the Ru-P interactions was further evaluated by means of a distortion/interaction analysis. The $\Delta \mathrm{E}_{\text {int }}$ values show that the stabilization trends are $\eta^{5}-\mathrm{C}_{5} \mathrm{Me}_{5}<\eta^{5}-\mathrm{C}_{5} \mathrm{H}_{5} \approx \eta^{5}-\mathrm{C}_{9} \mathrm{H}_{7}$ and $[\mathrm{Cl}]^{-} \ll\left[\mathrm{SnH}_{3}\right]^{-}<\left[\mathrm{SnCl}_{3}\right]^{-}$.

\section{Experimental section}

\subsection{General considerations}

All experiments were carried out under an atmosphere of argon by Schlenk techniques. Solvents were dried by the usual procedures [14] and, prior use, distilled under argon. The starting materials $\left[\mathrm{RuCl}\left(\eta^{5}-\mathrm{C}_{5} \mathrm{H}_{5}\right)\left(\mathrm{PPh}_{3}\right)_{2}\right]$ [15], [RuCl$\left.\left(\eta^{5}-\mathrm{C}_{5} \mathrm{Me}_{5}\right)\left(\mathrm{PPh}_{3}\right)_{2}\right][16]$ and $\left[\mathrm{RuCl}\left(\eta^{5}-\mathrm{C}_{9} \mathrm{H}_{7}\right)\left(\mathrm{PPh}_{3}\right)_{3}\right]$ [17] were prepared as described in the literature. All reagents were obtained from commercial sources. NMR spectra were recorded at room temperature on Bruker ARX400, Bruker DPX-600 instrument, with resonating frequencies $400 \mathrm{MHz}\left({ }^{1} \mathrm{H}\right), 161 \mathrm{MHz}\left({ }^{31} \mathrm{P}\left\{{ }^{1} \mathrm{H}\right\}\right), 100 \mathrm{MHz}\left({ }^{13} \mathrm{C}\left\{{ }^{1} \mathrm{H}\right\}\right)$, and $223 \mathrm{MHz}$ $\left({ }^{119} \mathrm{Sn}\right.$ and $\left.{ }^{119} \mathrm{Sn}\left\{{ }^{1} \mathrm{H}\right\}\right)$ using the solvents as the internal lock. ${ }^{1} \mathrm{H}$ and ${ }^{13} \mathrm{C}\left\{{ }^{1} \mathrm{H}\right\}$ signals are referred to internal TMS, those of ${ }^{31} \mathrm{P}\left\{{ }^{1} \mathrm{H}\right\}$ to $85 \%$ $\mathrm{H}_{3} \mathrm{PO}_{4}$ and ${ }^{119} \mathrm{Sn}$ shifts with respect to $\mathrm{Sn}\left(\mathrm{CH}_{3}\right)_{4}$; downfield shifts (expressed in ppm) are considered positive. ${ }^{1} \mathrm{H}$ and ${ }^{13} \mathrm{C}\left\{{ }^{1} \mathrm{H}\right\}$ NMR signal assignments were confirmed by $\left\{{ }^{1} \mathrm{H},{ }^{1} \mathrm{H}\right\} \operatorname{COSY},\left\{{ }^{1} \mathrm{H},{ }^{13} \mathrm{C}\right\}$ HSQC and DEPT experiments. Coupling constants are given in hertz. Infrared spectra were run on a Jasco FT/IR (ATR) spectrometer. C, H analyses were carried out with a Carlo Erba 1108 analyzer. Optical rotation values were recorded on a Jasco P-2000 polarimeter.

\subsection{Preparation of $\mathrm{Ph}_{2} \mathrm{POCHPhCHPhOPPh}_{2}(\boldsymbol{L}) .^{7}$}

A round-bottom flask was charged with a mixture of (R,R)(+)-hydrobenzoin (1.00 g, $4.71 \mathrm{mmol}$ ) and $10 \mathrm{~mL}$ of THF. The solution was cooled to $0{ }^{\circ} \mathrm{C}$ and $3.8 \mathrm{~mL}$ of ${ }^{\mathrm{n}} \mathrm{BuLi}(9.42 \mathrm{mmol}, 2.5 \mathrm{M}$ solution in hexane) were added dropwise. Then, $1.8 \mathrm{~mL}$ of $\mathrm{Ph}_{2} \mathrm{PCl}$ $(9.42 \mathrm{mmol})$ were slowly added. The reaction mixture was allowed to reach room temperature, filtered with a cannula, and the filtrate was concentrated under reduced pressure to produce a white oil. The oil obtained was stirred with ethanol $(20 \mathrm{~mL})$ resulting in a white solid which was filtered, washed with ethanol $(10 \mathrm{~mL})$ and dried under reduced pressure.

Yield: 56\%. Anal. Calc for $\mathrm{C}_{38} \mathrm{H}_{32} \mathrm{O}_{2} \mathrm{P}_{2}$ (582.62): C, 78.34; $\mathrm{H}, 5.54$. Found: C, 78.68; $\mathrm{H}, 5.23 .{ }^{1} \mathrm{H}$ NMR $\left(\mathrm{CHCl}_{3}-d_{1}, 25^{\circ} \mathrm{C}\right) \delta: 7.80-6.85(\mathrm{~m}$, $30 \mathrm{H}, \mathrm{Ph}), 5.08(\mathrm{~m}, 2 \mathrm{H}, \mathrm{CH} \mathrm{L}) \mathrm{ppm} .{ }^{31} \mathrm{P}\left\{{ }^{1} \mathrm{H}\right\}$ NMR $\left(\mathrm{CHCl}_{3}-\mathrm{d}_{1}, 25^{\circ} \mathrm{C}\right) \delta$ : 109.7 (s) ppm. [ $\alpha]_{\mathrm{D}}^{27}: 25 . \overline{7}$ (c $0.06, \mathrm{CHCl}_{3}$ ).

\subsection{Synthesis of complexes}

\subsection{1. $\left[\mathrm{RuCl}\left(\mathrm{C} p^{\prime}\right) L\right]\left[C p^{\prime}=\eta^{5}-\mathrm{C}_{5} \mathrm{H}_{5}(\mathbf{1 a}), \eta^{5}-\mathrm{C}_{5} \mathrm{Me}_{5}(\mathbf{1} \boldsymbol{b}), \eta^{5}-\mathrm{C}_{9} \mathrm{H}_{7}\right.$ (1c)]}

An excess of $\mathrm{Ph}_{2} \mathrm{POCHPhCHPhOPPh} 2(\mathbf{L})(0.70 \mathrm{mmol})$ was added to a solution of $\left[\left(\mathrm{RuCl}\left(\mathrm{Cp}^{\prime}\right)\left(\mathrm{PPh}_{3}\right)_{2}\right](0.64 \mathrm{mmol})\right.$ in toluene
$(30-40 \mathrm{~mL})$. The reaction mixture was refluxed for $3 \mathrm{~h}$ and allowed to cool to room temperature. The solvent was removed under vacuum, and the residue was treated with ethanol ( $3 \mathrm{~mL})$, affording products that yellow $(\mathbf{1 a}, \mathbf{1 b})$ or red-orange $(\mathbf{1 c})$ that were filtered and crystallized from $\mathrm{CH}_{2} \mathrm{Cl}_{2}$ and ethanol (2:5).

(1a) Yield: 79\%. Anal. Calc. for $\mathrm{C}_{43} \mathrm{H}_{37} \mathrm{ClO}_{2} \mathrm{P}_{2} \mathrm{Ru}$ (784.24): C, 65.86; $\mathrm{H}, 4.76$. Found: $\mathrm{C}, 65.92 ; \mathrm{H}, 4.65 .{ }^{1} \mathrm{H}$ NMR $\left(\mathrm{CH}_{2} \mathrm{Cl}_{2}-\mathrm{d}_{2}\left(25^{\circ} \mathrm{C}\right) \delta\right.$ : $7.70-6.70(\mathrm{~m}, 30 \mathrm{H}, \mathrm{Ph}), 6.03\left(\mathrm{dd},{ }^{3} \mathrm{~J}_{\mathrm{H}-\mathrm{H}}=7.6 \mathrm{~Hz},{ }^{3} \mathrm{~J}_{\mathrm{H}-\mathrm{P}}=14.2 \mathrm{~Hz}, 1 \mathrm{H}\right.$, $\mathrm{CH}$ L), 5.16 (cdd, $\left.{ }^{3} \mathrm{~J}_{\mathrm{H}-\mathrm{H}}=7.6 \mathrm{~Hz}, 1 \mathrm{H}, \mathrm{CH} \mathrm{L}\right), 4.51\left(\mathrm{~s}, 5 \mathrm{H}, \mathrm{C}_{5} \underline{\mathrm{H}}_{5}\right) \mathrm{ppm} .{ }^{31} \mathrm{P}$ $\left\{{ }^{\mathrm{T}} \mathrm{H}\right\} \operatorname{NMR}\left(\mathrm{CH}_{2} \mathrm{Cl}_{2}-d_{2}, 25^{\circ} \mathrm{C}\right) \delta: \overline{\mathrm{AB}}$ system, $\delta_{\mathrm{A}} 158.5, \delta_{\mathrm{B}} 153.1$ $\left({ }^{2} \mathrm{~J}_{\mathrm{AB}}=77.1 \mathrm{~Hz}\right)$ ppm. $[\alpha]_{\mathrm{D}}^{23}: 120.2\left(\right.$ c $\left.0.20, \mathrm{C}_{6} \mathrm{H}_{6}\right)$.

(1b) Yield: 70\%. Anal. Calc. for $\mathrm{C}_{48} \mathrm{H}_{47} \mathrm{ClO}_{2} \mathrm{P}_{2} \mathrm{Ru}$ (854.17): C, 67.43; $\mathrm{H}$, 5.55. Found: C, 67.76; $\mathrm{H}, 5.42 .{ }^{1} \mathrm{H}$ NMR $\left(\mathrm{CH}_{2} \mathrm{Cl}_{2}-\mathrm{d}_{2}, 25^{\circ} \mathrm{C}\right) \delta$ : $7.75-6.45(\mathrm{~m}, 30 \mathrm{H}, \mathrm{Ph}), 5.78\left(\mathrm{dd},{ }^{3} \mathrm{~J}-\mathrm{P}=13.4 \mathrm{~Hz},{ }^{3} \mathrm{~J}-\mathrm{H}=7.9 \mathrm{~Hz}, 1 \mathrm{H}\right.$, $\mathrm{CH} \mathrm{L}), 4.98\left(\mathrm{dd},{ }^{3} \mathrm{~J}_{\mathrm{H}-\mathrm{H}}=7.9 \mathrm{~Hz},{ }^{3} \mathrm{~J}_{\mathrm{H}-\mathrm{P}}=2.8 \mathrm{~Hz}, 1 \mathrm{H}, \mathrm{CH} \mathrm{L}\right), 1.23(\mathrm{~s}, 15 \mathrm{H}$, $\left.\mathrm{C}_{5} \mathrm{Me}_{5}\right) \mathrm{ppm} .{ }^{31} \mathrm{P}\left\{{ }^{1} \mathrm{H}\right\} \mathrm{NMR}\left(\mathrm{CH}_{2} \mathrm{Cl}_{2}-d_{2}, 25^{\circ} \mathrm{C}\right) \delta$ : AB system, $\delta_{\mathrm{A}} 160.4$, $\delta_{\mathrm{B}} 156.6\left({ }^{2} \mathrm{JAB}=73.8 \mathrm{~Hz}\right)$ ppm. [ $\left.\alpha\right]_{\mathrm{D}}^{27}:-40.3\left(c 0.19, \mathrm{CHCl}_{3}\right)$.

(1c) Yield: $78 \%$ Anal. Calc. for $\mathrm{C}_{47} \mathrm{H}_{39} \mathrm{ClO}_{2} \mathrm{P}_{2} \mathrm{Ru}$ (834.30): C, 67.66; $\mathrm{H}, 4.71$. Found: $\mathrm{C}, 67.32 ; \mathrm{H}, 4.80 .{ }^{1} \mathrm{H}$ NMR $\left(400 \mathrm{MHz}, \mathrm{CH}_{2} \mathrm{Cl}_{2}-\mathrm{d}_{2}\right.$, $\left.25^{\circ} \mathrm{C}\right): \delta 7.86-6.47\left(\mathrm{~m}, 30 \mathrm{H}, \mathrm{Ph}, \mathrm{C}_{9} \mathrm{H}_{7}\right), 5.91\left(\mathrm{dd},{ }^{3} \mathrm{JH}-\mathrm{P}=13.1 \mathrm{~Hz},{ }^{3} \mathrm{JH}_{\mathrm{H}}\right.$ $\mathrm{H}=8.2 \mathrm{~Hz}, \mathrm{CH} \mathrm{L}), 5.15(\mathrm{~m}, 1 \mathrm{H}, \mathrm{CH} \mathrm{L}), 4.68\left(\mathrm{~m}, 1 \mathrm{H}, \mathrm{H}_{2}, \mathrm{C}_{9} \mathrm{H}_{7}\right), 4.21(\mathrm{~s}$, $\left.1 \mathrm{H}, \mathrm{H}_{1,3}, \mathrm{C}_{9} \overline{\mathrm{H}}_{7}\right), 4.10\left(\mathrm{~s}, 1 \mathrm{H}, \mathrm{H}_{1,3}, \mathrm{C}_{9} \mathrm{H}_{7}\right) .{ }^{31} \mathrm{P}\left\{{ }^{1} \mathrm{H}\right\}$ NMR $(161 \mathrm{MHz}$, $\left.\mathrm{CH}_{2} \mathrm{Cl}_{2}-d_{2}, 25^{\circ} \mathrm{C}\right) \delta$ : AB system, $\delta_{\mathrm{A}} 160.5, \delta_{\mathrm{B}} 157.5\left({ }^{2} \mathrm{JAB}=72 \mathrm{~Hz}\right) .{ }^{13} \mathrm{C}$ $\left\{{ }^{1} \mathrm{H}\right\}$ NMR $\left(\mathrm{CH}_{2} \mathrm{Cl}_{2}-d_{2}, 25^{\circ} \mathrm{C}\right) \delta: 146.9-127.4\left(\mathrm{~m}, \mathrm{Ph}+\mathrm{C}_{5-8} \mathrm{C}_{9} \mathrm{H}_{7}\right)$, $117.5\left(\mathrm{~d},{ }^{2} \mathrm{~J}_{\mathrm{C}-\mathrm{P}}=5.1 \mathrm{~Hz}, \mathrm{C}_{4,9} \mathrm{C}_{9} \mathrm{H}_{7}\right), 109.2\left(\mathrm{~d},{ }^{2} \mathrm{~J}_{\mathrm{C}-\mathrm{P}}=7.3 \mathrm{~Hz}, \mathrm{C}_{4,9} \mathrm{C}_{9} \mathrm{H}_{7}\right)$, $89.3\left(\mathrm{~s}, \mathrm{C}_{2} \mathrm{C}_{9} \mathrm{H}_{7}\right.$ ), 85.2 (dd, $\left.{ }^{2} \mathrm{JC}_{\mathrm{C}} \mathrm{P}=8.7 \mathrm{~Hz},{ }^{3} \mathrm{~J} \mathrm{C}-\mathrm{P}=1.8 \mathrm{~Hz}, \underline{\mathrm{CH}} \mathrm{L}\right), 80.8$ $\left(\mathrm{d},{ }^{2} \mathrm{~J}_{\mathrm{C}-\mathrm{P}}=2.4 \mathrm{~Hz}, \mathrm{C}_{1,3} \mathrm{C}_{9} \mathrm{H}_{7}\right), 70.4\left(\mathrm{~d},{ }^{2} \mathrm{JC}_{\mathrm{C}-\mathrm{P}}=14.2 \mathrm{~Hz}, \underline{\mathrm{CH}} \mathrm{L}\right), 64.8(\mathrm{~s}$, $\left.\mathrm{C}_{1,3} \mathrm{C}_{9} \mathrm{H}_{7}\right)$ ppm. $[\alpha]_{\mathrm{D}}^{27}:-141.1\left(\right.$ c $\left.0.08, \mathrm{CHCl}_{3}\right)$.

\subsubsection{Preparation of $\left[\mathrm{Ru}\left(\mathrm{SnCl}_{3}\right)\left(C p^{\prime}\right) L\right]\left[C p^{\prime}=\eta^{5}-\mathrm{C}_{5} \mathrm{H}_{5}\right.$ (2a), $\eta^{5}$ - $\mathrm{C}_{5} \mathrm{Me}_{5}$ (2b), $\left.\eta^{5}-\mathrm{C}_{9} \mathrm{H}_{7}(\mathbf{2 c})\right]$}

A Schlenk tube was charged with $0.25 \mathrm{mmol}$ of $\left[\mathrm{RuCl}\left(\mathrm{Cp}^{\prime}\right) \mathrm{L}\right](\mathbf{1 a}-$ c) and $\mathrm{SnCl}_{2} \cdot 2 \mathrm{H}_{2} \mathrm{O}(0.95 \mathrm{mmol})$ in $20 \mathrm{~mL}$ of ethanol. The reaction mixture was refluxed for $2 \mathrm{~h}$ and then the solvent was removed under reduce pressure to give a residue was treated with hexane $(2 \mathrm{~mL})$, affording products that yellow $(\mathbf{2 a}, \mathbf{2 b})$ or orange $(\mathbf{2 c})$ that were filtered and washed with hexane and dried under vacuum.

(2a) Yield: 58\%. Anal. Calc. for $\mathrm{C}_{43} \mathrm{H}_{37} \mathrm{Cl}_{3} \mathrm{O}_{2} \mathrm{P}_{2} \mathrm{RuSn}$ (973.83): $\mathrm{C}$, 53.04; $\mathrm{H}, 3.83$. Found: $\mathrm{C}, 52.89 ; \mathrm{H}, 3.92 .{ }^{1} \mathrm{H}$ NMR $\left(\mathrm{CH}_{2} \mathrm{Cl}_{2}-\mathrm{d}_{2}, 25^{\circ} \mathrm{C}\right)$ : $\delta 7.78-6.85(\mathrm{~m}, 30 \mathrm{H}, \mathrm{Ph}), 5.93\left(\mathrm{dd},{ }^{3} \mathrm{~J}-\mathrm{H}=8.0 \mathrm{~Hz},{ }^{3} \mathrm{~J}-\mathrm{P}=11.6 \mathrm{~Hz}\right.$, $1 \mathrm{H}, \mathrm{CH} \mathrm{L}$ ), 5.02 (cdd, $\left.{ }^{3} \mathrm{~J}_{\mathrm{H}-\mathrm{H}}={ }^{3} \mathrm{~J}_{\mathrm{H}-\mathrm{P}}=8.0 \mathrm{~Hz}, 1 \mathrm{H}, \mathrm{CH} \mathrm{L}\right), 4.87(\mathrm{~s}, 5 \mathrm{H}$, $\left.\mathrm{C}_{5} \mathrm{H}_{5}\right)$ ppm. ${ }^{31} \mathrm{P}\left\{{ }^{1} \mathrm{H}\right\}$ NMR $\left(\mathrm{CH}_{2} \mathrm{Cl}_{2}-\mathrm{d}_{2}, 25^{\circ} \mathrm{C}\right): \bar{\delta} \mathrm{AB}, \delta_{\mathrm{A}} 159.7$ $\left({ }^{2} \mathrm{JP}_{\mathrm{P}-\mathrm{Sn}}^{119} \approx 468 \mathrm{~Hz},{ }^{2} \mathrm{~J}_{\mathrm{P}-\mathrm{Sn}}^{117} \approx 448 \mathrm{~Hz}\right), \quad \delta_{\mathrm{B}} 158.7 \quad\left({ }^{2} \mathrm{JP}_{\mathrm{P}-\mathrm{Sn}}^{119} \approx 444 \mathrm{~Hz}\right.$, $\left.{ }^{2} \mathrm{JP}_{\mathrm{P}-\mathrm{Sn}}^{117} \approx 423 \mathrm{~Hz}\right)\left({ }^{2} \mathrm{~J}_{\mathrm{AB}}=54.5 \mathrm{~Hz}\right) \mathrm{ppm} .{ }^{119} \mathrm{Sn}\left\{{ }^{1} \mathrm{H}\right\} \mathrm{NMR}\left(\mathrm{CH}_{2} \mathrm{Cl}_{2}-\mathrm{d}_{2}\right.$, $\left.25^{\circ} \mathrm{C}\right): \delta-7.4$ (cdd, $\left.{ }^{2} \mathrm{JSn}-\mathrm{P} \approx 458 \mathrm{~Hz}\right) \cdot[\alpha]_{\mathrm{D}}^{27}: 125.6\left(c 0.20, \mathrm{CH}_{2} \mathrm{Cl}_{2}\right)$.

(2b) Yield: 56\%. Anal. Calc. for $\mathrm{C}_{48} \mathrm{H}_{47} \mathrm{Cl}_{3} \mathrm{O}_{2} \mathrm{P}_{2} \mathrm{RuSn}$ (1044.01): $\mathrm{C}$, 55.17; $\mathrm{H}, 4.54$. Found: $\mathrm{C}, 55.10 ; \mathrm{H}, 4.55 \% .{ }^{1} \mathrm{H}$ NMR $\left(\mathrm{CH}_{2} \mathrm{Cl}_{2}-\mathrm{d}_{2}, 25{ }^{\circ} \mathrm{C}\right)$ : $\delta 7.82-6.70(\mathrm{~m}, 30 \mathrm{H}, \mathrm{Ph}), 5.94\left(\mathrm{dd},{ }^{3} \mathrm{~J}-\mathrm{P}=11.8 \mathrm{~Hz},{ }^{3} \mathrm{~J}-\mathrm{H}=7.8 \mathrm{~Hz}, 1 \mathrm{H}\right.$, CH L), 4.77 (dd, $\left.{ }^{3} \mathrm{JH}_{\mathrm{H}-\mathrm{P}}=9.5 \mathrm{~Hz},{ }^{3} \mathrm{~J}_{\mathrm{H}-\mathrm{H}}=7.8 \mathrm{~Hz}, 1 \mathrm{H}, \mathrm{CH} \mathrm{L}\right), 1.41(\mathrm{~s}, 15 \mathrm{H}$, $\left.\overline{\mathrm{C}}_{5} \underline{\mathrm{Me}}_{5}\right)$ ppm. ${ }^{31} \mathrm{P}\left\{{ }^{1} \mathrm{H}\right\} \quad \mathrm{NMR}\left(\mathrm{CH}_{2} \mathrm{Cl}_{2}-d_{2}, 25^{\circ} \overline{\mathrm{C}}\right): \delta 170.5$ (d, $\left.{ }^{2} \mathrm{JPP}=55.1 \mathrm{~Hz}, \quad{ }^{2} \mathrm{JP}-119 \mathrm{Sn} \approx 427 \mathrm{~Hz}, \quad{ }^{2} \mathrm{JP}-117 \mathrm{Sn} \approx 406 \mathrm{~Hz}\right), 156.5(\mathrm{~d}$, $\left.{ }^{2} \mathrm{JPP}_{\mathrm{PP}}=55.1 \mathrm{~Hz},{ }^{2} \mathrm{~J}_{\mathrm{P}-119 \mathrm{Sn}} \approx 422 \mathrm{~Hz},{ }^{2} \mathrm{JP}_{\mathrm{P}-117 \mathrm{Sn}} \approx 403 \mathrm{~Hz}\right)$ ppm. ${ }^{13} \mathrm{C}\left\{{ }^{1} \mathrm{H}\right\}$ $\operatorname{NMR}\left(\mathrm{CH}_{2} \mathrm{Cl}_{2}-\mathrm{d}_{2}, 25^{\circ} \mathrm{C}\right): \delta 144.3-127.3(\mathrm{Ph}), 94.8\left(\mathrm{~s}, \mathrm{C}_{5} \mathrm{Me}_{5}\right), 85.9(\mathrm{~d}$, $\left.{ }^{2} \mathrm{JC}_{\mathrm{C}}=8.7 \mathrm{~Hz}, \underline{\mathrm{CH} \mathrm{L}}\right), 83.2\left(\mathrm{~d},{ }^{2} \mathrm{~J}_{\mathrm{C}-\mathrm{P}}=6.6 \mathrm{~Hz}, \underline{\mathrm{CH} \mathrm{L}}\right), 10.1\left(\mathrm{~s}, \mathrm{C}_{5} \mathrm{Me}_{5}\right)$ ppm. ${ }^{119} \mathrm{Sn}\left\{{ }^{1} \mathrm{H}\right\}$ NMR $\left(\mathrm{CH}_{2} \mathrm{Cl}_{2}-d_{2}, 25^{\circ} \mathrm{C}\right):{ }^{\delta}-20.3$ (cdd, ${ }^{2} \mathrm{~J}_{\mathrm{Sn}}$ $\mathrm{p} \approx 421 \mathrm{~Hz}$ ) ppm. $[\alpha]_{\mathrm{D}}^{27}: 27.3\left(\right.$ c $\left.0.20, \mathrm{CHCl}_{3}\right)$.

(2c) Yield: $50 \%$. Anal. Calc. for $\mathrm{C}_{47} \mathrm{H}_{39} \mathrm{Cl}_{3} \mathrm{O}_{2} \mathrm{P}_{2} \mathrm{RuSn}$ (1023.95): C, 55.08; $\mathrm{H}, 3.84$. Found: $\mathrm{C}, 55.06 ; \mathrm{H}, 3.90 \% .{ }^{1} \mathrm{H} \mathrm{NMR}\left(\mathrm{CH}_{2} \mathrm{Cl}_{2}-\mathrm{d}_{2}\right.$, $\left.25^{\circ} \mathrm{C}\right): \delta 8.30-6.15\left(34 \mathrm{H}, \mathrm{Ph}+\mathrm{H}_{5-7} \mathrm{C}_{9} \mathrm{H}_{7}\right), 5.68\left(\mathrm{dd},{ }^{3} \mathrm{~J}_{\mathrm{H}-\mathrm{P}}=12.1 \mathrm{~Hz}\right.$, $\left.{ }^{3} \mathrm{~J}_{\mathrm{H}-\mathrm{H}}=8.1 \mathrm{~Hz}, 1 \mathrm{H}, \underline{\mathrm{CH}} \mathrm{L}\right), 5.22\left(\mathrm{br} \mathrm{d},{ }^{3} \mathrm{~J}_{\mathrm{H}-\mathrm{H}}=2.5 \mathrm{~Hz}, 1 \mathrm{H}, \mathrm{H}_{2} \mathrm{C}_{9} \mathrm{H}_{7}\right), 5.07$ (br s, $\left.1 \mathrm{H}, \mathrm{H}_{1,3} \mathrm{C}_{9} \mathrm{H}_{7}\right), \overline{4} .94$ (dd, ${ }^{3} \mathrm{~J}_{\mathrm{H}-\mathrm{P}}=9.2 \mathrm{~Hz},{ }^{3} \mathrm{~J}_{\mathrm{H}-\mathrm{H}}=8.1 \mathrm{~Hz}, 1 \mathrm{H}, \mathrm{CH} \mathrm{L}$ ), 4.59 (br s, $\left.1 \mathrm{H}, \mathrm{H}_{1,3} \mathrm{C}_{9} \mathrm{H}_{7}\right)$ ppm. ${ }^{13} \mathrm{C}\left\{{ }^{1} \mathrm{H}\right\}$ NMR $\left(\mathrm{CH}_{2} \mathrm{Cl}_{2}-\mathrm{d}_{2}, 25^{\circ} \mathrm{C}\right)$ : $\delta$ 146.2-124.1 ( $\left.\mathrm{Ph}+\mathrm{C}_{5-8} \mathrm{C}_{9} \mathrm{H}_{7}\right), 110.0\left(\mathrm{~d},{ }^{2} \mathrm{~J}_{\mathrm{C}-\mathrm{P}}=2.7 \mathrm{~Hz}, \mathrm{C}_{4,9} \mathrm{C}_{9} \mathrm{H}_{7}\right)$, $104.2\left(\mathrm{~d},{ }^{2} \mathrm{~J}_{\mathrm{C}-\mathrm{P}}=3.7 \mathrm{~Hz}, \mathrm{C}_{4,9} \mathrm{C}_{9} \mathrm{H}_{7}\right), 88.7$ (br s, $\left.\mathrm{C}_{2} \mathrm{C}_{9} \mathrm{H}_{7}\right), 86.7$ (dd, ${ }^{2} \mathrm{~J}_{-}$ $\left.\mathrm{P}=9.8 \mathrm{~Hz},{ }^{3} \mathrm{~J}_{\mathrm{C}-\mathrm{P}}=1.1 \mathrm{~Hz}, \underline{\mathrm{CH} \mathrm{L}}\right), 82.7\left(\mathrm{br} \mathrm{d},{ }^{2} \mathrm{~J}_{\mathrm{C}-\mathrm{P}}=5.7 \mathrm{~Hz}, \underline{\mathrm{CH} \mathrm{L}), 73.5}\right.$ 
(s, $\mathrm{C}_{1,3} \mathrm{C}_{9} \mathrm{H}_{7}$ ), 69.2 (br d, ${ }^{2} \mathrm{~J}$ - $\mathrm{P}=6.5 \mathrm{~Hz}, \mathrm{C}_{1,3} \mathrm{C}_{9} \mathrm{H}_{7}$ ) ppm. ${ }^{31} \mathrm{P}\left\{{ }^{1} \mathrm{H}\right\} \mathrm{NMR}$ $\left(\mathrm{CH}_{2} \mathrm{Cl}_{2}-d_{2}, 25^{\circ} \mathrm{C}\right) \delta: 163.6\left(\mathrm{~d},{ }^{2} \mathrm{~J}_{\mathrm{PP}}=50.8 \mathrm{~Hz},{ }^{2} \mathrm{JP}-\mathrm{Sn}=428.0 \mathrm{~Hz}\right.$, $\left.{ }_{\mathrm{J}}^{2} \mathrm{JP}_{\mathrm{P}-\mathrm{Sn}}^{117}=416.3 \mathrm{~Hz}\right), \quad 159.1 \quad\left(\mathrm{~d}, \quad{ }^{2} \mathrm{JPP}_{\mathrm{PP}}=50.8, \quad{ }_{2}^{2} \mathrm{JP}_{\mathrm{P}-\mathrm{Sn}}=363.1 \mathrm{~Hz}\right.$, $\left.{ }_{\mathrm{JP}-\mathrm{Sn}}^{117}=349.1 \mathrm{~Hz}\right) \mathrm{ppm} .{ }^{119} \mathrm{Sn}\left\{{ }^{1} \mathrm{H}\right\} \mathrm{NMR}\left(\mathrm{CH}_{2} \mathrm{Cl}_{2}-d_{2}, 25^{\circ} \mathrm{C}\right): \delta-36.7$ $\left(\mathrm{dd},{ }^{2} \mathrm{~J}_{\mathrm{Sn}-\mathrm{P}}=430.8 \mathrm{~Hz},{ }^{2} \mathrm{JSn}_{\mathrm{S}-\mathrm{P}}=365.2 \mathrm{~Hz}\right) \mathrm{ppm}$. [ $\left.\alpha\right]_{\mathrm{D}}^{27}$ : -170.6 ( c 0.19, $\left.\mathrm{CHCl}_{3}\right)$.

\subsection{3. $\left[\mathrm{Ru}\left(\mathrm{SnH}_{3}\right)\left(\mathrm{Cp}^{\prime}\right) L\right]\left[C p^{\prime}=\eta^{5}-\mathrm{C}_{5} \mathrm{H}_{5}(\mathbf{3 a}), \eta^{5}-\mathrm{C}_{5} \mathrm{Me}_{5}(\mathbf{3 b}), \eta^{5}-\mathrm{C}_{9} \mathrm{H}_{7}\right.$ (3c)]}

An excess of $\mathrm{NaBH}_{4}(1.00 \mathrm{mmol})$ in $20 \mathrm{~mL}$ of ethanol was added to a suspension of $\left[\mathrm{Ru}\left(\mathrm{SnCl}_{3}\right)(\mathrm{Cp}) \mathrm{L}\right](\mathbf{2 a}-\mathbf{c})(0.05 \mathrm{mmol})$ in ethanol. The reaction mixture was stirred at room temperature for $1 \mathrm{~h}$ and then the solvent was removed under vacuum giving a yellow solid. The complex was extracted from this solid with $15 \mathrm{~mL}$ of toluene using a celite ${ }^{\circledR}$ column for filtration. Extracts were evaporated to dryness to give an orange oil that was treated with ethanol $(3 \mathrm{~mL})$ giving a yellow product that was filtered out and dried under vacuum.

(3a) Yield: 52\%. Anal. Calc. for $\mathrm{C}_{43} \mathrm{H}_{40} \mathrm{O}_{2} \mathrm{P}_{2} \mathrm{RuSn}$ (870.50): C, 59.33; H, 4.63. Found: C, 59.70; H, 5.01\%. FT-IR (ATR): $v_{\text {Sn-H }} 1730$ (m) $\mathrm{cm}^{-1}{ }^{1} \mathrm{H}$ NMR $\left(\mathrm{C}_{6} \mathrm{H}_{6}-d_{6}, 25^{\circ} \mathrm{C}\right) ; \delta 8.00-6.70(\mathrm{~m}, 30 \mathrm{H}, \mathrm{Ph}), 6.24$ $\left(\mathrm{dd},{ }^{3} \mathrm{~J}_{\mathrm{H}-\mathrm{P}}=11.6 \mathrm{~Hz},{ }^{3} \mathrm{~J}_{\mathrm{H}-\mathrm{H}}=8.4 \mathrm{~Hz}, 1 \mathrm{H}, \mathrm{CH} \mathrm{L}\right), 5.32\left(\mathrm{cdd},{ }^{3} \mathrm{~J}_{\mathrm{H}-\mathrm{P}}={ }^{3} \mathrm{~J}_{\mathrm{H}-}\right.$ $\mathrm{H}=8.4 \mathrm{~Hz}, 1 \mathrm{H}, \mathrm{CH} \mathrm{L}), 4.60$ (br s, $\left.5 \mathrm{H}, \mathrm{C}_{5} \mathrm{H}_{5}\right), 4.28\left(\mathrm{~s}, \mathrm{JH}_{\mathrm{H}-\mathrm{Sn}}^{119}=1262.1 \mathrm{~Hz}\right.$, $\left.\mathrm{J}_{\mathrm{H}-\mathrm{Sn}}^{117}=1206.1 \mathrm{~Hz}, 3 \mathrm{H}, \mathrm{SnH}_{3}\right) \mathrm{ppm} .{ }^{31} \overline{\mathrm{P}}\left\{{ }^{1} \mathrm{H}\right\} \operatorname{NMR}\left(\mathrm{C}_{6} \mathrm{H}_{6}-d_{6}, 25^{\circ} \mathrm{C}\right) \delta$ : AB system, $\delta_{\mathrm{A}} 163.7,\left({ }^{2} \mathrm{JP}_{\mathrm{P}-119 \mathrm{Sn}} \approx 289 \mathrm{~Hz},{ }^{2} \mathrm{JP}-117 \mathrm{Sn} \approx 277 \mathrm{~Hz}\right), \delta_{\mathrm{B}} 160.1$ $\left({ }^{2} \mathrm{JP}-119 \mathrm{Sn} \approx 297 \mathrm{~Hz},{ }^{2} \mathrm{JP}-117 \mathrm{Sn} \approx 285 \mathrm{~Hz}\right)\left({ }^{2} \mathrm{~J}_{\mathrm{AB}}=62.0 \mathrm{~Hz}\right) \mathrm{ppm} .{ }^{119} \mathrm{Sn}$ $\left\{{ }^{1} \mathrm{H}\right\}$ NMR $\left(\mathrm{C}_{6} \mathrm{H}_{6}-d_{6}, 25^{\circ} \mathrm{C}\right) \delta: \mathrm{ABMX}_{3}$ system $\delta_{\mathrm{M}}=-323.2 \mathrm{ppm}$ $[\alpha]_{\mathrm{D}}^{27}: 144.8\left(c \mathrm{0} .20, \mathrm{C}_{6} \mathrm{H}_{6}\right)$.

(3b) Yield: 57\%. Anal. Calc. for $\mathrm{C}_{48} \mathrm{H}_{50} \mathrm{O}_{2} \mathrm{P}_{2} \mathrm{RuSn}$ (942.13): C, 61.14; H, 5.35. Found: C, 61.62; H, 5.60\%. FT-IR (ATR): $v_{\text {Sn-H }} 1698$ $(\mathrm{m}) \mathrm{cm}^{-1} .{ }^{1} \mathrm{H}$ NMR $\left(\mathrm{C}_{6} \mathrm{H}_{6}-d_{6}, 25^{\circ} \mathrm{C}\right): \delta 8.12-6.45(\mathrm{~m}, 30 \mathrm{H}, \mathrm{Ph}), 6.08$ $\left(\mathrm{dd},{ }^{3} \mathrm{~J}_{\mathrm{H}-\mathrm{P}}=12.4 \mathrm{~Hz},{ }^{3} \mathrm{~J}_{\mathrm{H}-\mathrm{H}}=7.9 \mathrm{~Hz}, 1 \mathrm{H}, \mathrm{CH} \mathrm{L}\right), 5.16\left(\mathrm{dd},{ }^{3} \mathrm{~J}_{\mathrm{H}-\mathrm{H}}=7.9 \mathrm{~Hz}\right.$,

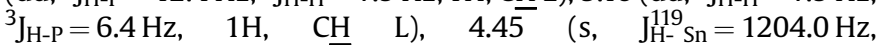
$\left.\mathrm{J}_{\mathrm{H}-\mathrm{Sn}}^{117}=1152.1 \mathrm{~Hz}, 3 \mathrm{H}, \mathrm{Sn} \overline{\mathrm{H}}_{3}\right), 1.43$ (br s, $\left.15 \mathrm{H}, \mathrm{C}_{5} \mathrm{Me}_{5}\right) \mathrm{ppm} .{ }^{31} \mathrm{P}\left\{{ }^{1} \mathrm{H}\right\}$ NMR $\left(\mathrm{C}_{6} \mathrm{H}_{6}-d_{6}, \quad 25^{\circ} \mathrm{C}\right) \quad \delta: \quad \mathrm{AB}$ system, $\delta_{\mathrm{A}} 165.7, \quad \delta_{\mathrm{B}} 163.8$ $\left({ }^{2} \mathrm{~J}_{\mathrm{AB}}=60.2 \mathrm{~Hz}\right)$ ppm. $[\alpha]_{\mathrm{D}}^{27}:-58.5$ (c 0.20, Toluene).

(3c) Yield: 66\%. Anal. Calc. for $\mathrm{C}_{47} \mathrm{H}_{42} \mathrm{O}_{2} \mathrm{P}_{2} \mathrm{RuSn}$ (922.07): $\mathrm{C}$, 61.17; H, 4.59. Found: C, 59.41; H, 4.45\%. FT-IR (ATR): $v_{\text {Sn-H }} 1738$ $(\mathrm{m}) \mathrm{cm}^{-1} .1 \mathrm{H}$ NMR $\left(\mathrm{C}_{6} \mathrm{H}_{6}-d_{6}, 25^{\circ} \mathrm{C}\right): \delta 8.20-6.25\left(\mathrm{~m}, 34 \mathrm{H}, \mathrm{Ph}+\mathrm{H}_{5-7}\right.$ $\left.\mathrm{C}_{9} \mathrm{H}_{7}\right), 5.85\left(\mathrm{dd},{ }^{3} \mathrm{~J}_{\mathrm{H}-\mathrm{P}}=12.2 \mathrm{~Hz},{ }^{3} \mathrm{~J}_{\mathrm{H}-\mathrm{H}}=8.0 \mathrm{~Hz}, 1 \mathrm{H}, \mathrm{CH} \mathrm{L}\right), 5.21\left(\mathrm{t},{ }^{3} \mathrm{~J}_{\mathrm{H}-}\right.$ $\left.\mathrm{H}=2.6 \mathrm{~Hz}, 1 \mathrm{H}, \mathrm{H}_{2} \mathrm{C}_{9} \mathrm{H}_{7}\right), 5.04\left(\mathrm{cdd},{ }^{3} \mathrm{~J}_{\mathrm{H}-\mathrm{P}}={ }^{3} \mathrm{~J}_{\mathrm{H}-\mathrm{H}}=7.2 \mathrm{~Hz}, 1 \mathrm{H}, \mathrm{CH} \mathrm{L}\right)$, $4.70\left(\mathrm{~s}, \quad 1 \mathrm{H}, \mathrm{H}_{1,3} \mathrm{C}_{9} \mathrm{H}_{7}\right), 4.60\left(\mathrm{~s}, 1 \mathrm{H}, \mathrm{H}_{1,3} \mathrm{C}_{9} \mathrm{H}_{7}\right), 4.09$ (s, $\left.\mathrm{J}_{\mathrm{H}-\mathrm{Sn}}^{119}=1316 \mathrm{~Hz}, \mathrm{JH}_{\mathrm{H}-\mathrm{Sn}}^{117}=1256 \mathrm{~Hz}, 3 \mathrm{H}, \mathrm{SnH}_{3}\right) \mathrm{ppm} .{ }^{31} \mathrm{P}\left\{{ }^{1} \mathrm{H}\right\} \mathrm{NMR}$ $\left(\mathrm{C}_{6} \mathrm{H}_{6}-d_{6}, 25^{\circ} \mathrm{C}\right) \delta: \quad \mathrm{AB}$ system, $\delta_{\mathrm{A}} 165.3 \quad\left({ }^{2} \mathrm{~J}_{\mathrm{P}-\mathrm{Sn}}^{119} \approx 266.0 \mathrm{~Hz}\right.$, $\left.{ }^{2} \mathrm{JP}_{\mathrm{P}-\mathrm{Sn}}^{117} \approx 256.0 \mathrm{~Hz}\right), \delta_{\mathrm{B}} 163.8\left({ }^{2} \mathrm{JP}_{\mathrm{P}-\mathrm{Sn}}^{119} \approx 288.0 \mathrm{~Hz},{ }^{2} \mathrm{JP}_{\mathrm{P}-\mathrm{Sn}}^{117} \approx 276.0 \mathrm{~Hz}\right)$ $\left({ }^{2} \mathrm{~J}_{\mathrm{AB}}=55.9 \mathrm{~Hz}\right)$ ppm. $[\alpha]_{\mathrm{D}}^{27}:-123.3\left(\right.$ c $\left.0.20, \mathrm{C}_{6} \mathrm{H}_{6}\right)$.

\subsection{4. $\left[R u\left(\mathrm{SnMe}_{3}\right)\left(C p^{\prime}\right) L\right]\left[C p^{\prime}=\eta^{5}-C_{5} H_{5}(\mathbf{4 a}), \eta^{5}-C_{5} M e_{5}(\mathbf{4 b}), \eta^{5}-\right.$ $\left.\mathrm{C}_{9} \mathrm{H}_{7}(\mathbf{4 c})\right]$}

An excess of MgBrMe $(0.60 \mathrm{mmol}, 0.2 \mathrm{~mL}$ of $3 \mathrm{M}$ solution in diethyl ether) was added to a suspension of $0.10 \mathrm{mmol}$ of the corresponding trichlorostannyl complexes $\left[\mathrm{Ru}\left(\mathrm{SnCl}_{3}\right)(\mathrm{Cp}) \mathrm{L}\right](\mathbf{2 a - c})$ in $20 \mathrm{~mL}$ of diethyl ether cooled to $-196^{\circ} \mathrm{C}$. The reaction mixture was allowed to reach room temperature and stirred for $6 \mathrm{~h}$. The solvent was removed under vacuum, and the brown residue was dissolved in toluene $(10 \mathrm{~mL})$ and filtered through celite ${ }^{\circledR}$. The solvent was removed under vacuum, and the brown residue was treated with ethanol ( $2 \mathrm{~mL})$, affording a yellow product that was filtered, washed with ethanol $(2 \times 3 \mathrm{~mL})$ and dried under reduced pressure.

(4a) Yield: 52\%. Anal. Calc. for $\mathrm{C}_{46} \mathrm{H}_{46} \mathrm{O}_{2} \mathrm{P}_{2} \mathrm{RuSn}$ (912.58): C, 60.54; $\mathrm{H}, 5.08$. Found: $\mathrm{C}, 60.72 ; \mathrm{H}, 5.19 \% .{ }^{1} \mathrm{H}$ NMR $\left(\mathrm{C}_{6} \mathrm{H}_{6}-d_{6}, 25{ }^{\circ} \mathrm{C}\right) \delta$ : $8.10-6.80(\mathrm{~m}, 30 \mathrm{H}, \mathrm{Ph}), 5.72\left(\mathrm{dd},{ }^{3} \mathrm{~J}-\mathrm{P}=13.2 \mathrm{~Hz},{ }^{3} \mathrm{~J}_{\mathrm{H}-\mathrm{H}}=9.2 \mathrm{~Hz}, 1 \mathrm{H}\right.$, $\mathrm{CH} \mathrm{L}), 5.19$ (cdd, $\left.{ }^{3} \mathrm{~J}_{\mathrm{H}-\mathrm{P}}={ }^{3} \mathrm{~J}_{\mathrm{H}-\mathrm{H}}=9.2 \mathrm{~Hz}, 1 \mathrm{H}, \mathrm{CH} \mathrm{L}\right), 4.70\left(\mathrm{~s}, 5 \mathrm{H}, \mathrm{C}_{5} \underline{\mathrm{H}}_{5}\right.$ ), $0.63\left(\mathrm{~s},{ }^{2} \mathrm{~J}_{\mathrm{H}-119 \mathrm{Sn}}=35.2 \mathrm{~Hz}, 9 \mathrm{H}, \mathrm{SnMe}_{3}\right) \mathrm{ppm} .{ }^{31} \mathrm{P}\left\{{ }^{1} \mathrm{H}\right\} \mathrm{NMR}\left(\mathrm{C}_{6} \mathrm{H}_{6}-d_{6}\right.$, $\left.25^{\circ} \mathrm{C}\right) \delta$ : AB system, $\delta_{\mathrm{A}} 164.5, \delta_{\mathrm{B}} 163.7\left({ }^{2} \mathrm{~J}_{\mathrm{AB}}=58.3 \mathrm{~Hz}\right) \mathrm{ppm} .{ }^{13} \mathrm{C}\left\{{ }^{1} \mathrm{H}\right\}$
$\operatorname{NMR}\left(\mathrm{C}_{6} \mathrm{H}_{6}-d_{6}, 25^{\circ} \mathrm{C}\right) \delta: 151.1-127.4(\mathrm{Ph}), 85.4\left(\mathrm{br} \mathrm{t},{ }^{2} \mathrm{~J}_{\mathrm{C}-\mathrm{P}}=3.0 \mathrm{~Hz}\right.$, CH L), 82.8 (s, CH L), $82.4\left(\mathrm{~s}, \underline{\mathrm{C}}_{5} \mathrm{H}_{5}\right),-1.4\left(\mathrm{~s}, \mathrm{~J}_{\mathrm{Sn}-\mathrm{C}}=80.6 \mathrm{~Hz}, \mathrm{SnMe}_{3}\right)$ ppm. ${ }^{119} \mathrm{Sn}\left\{{ }^{1} \mathrm{H}\right\} \quad$ NMR $\quad\left(\mathrm{C}_{6} \mathrm{H}_{6}-d_{6}, \quad 25^{\circ} \mathrm{C}\right) \quad \delta: 23.6 \quad$ (cdd, ${ }^{2} \mathrm{~J}_{\mathrm{Sn}-\mathrm{p}}^{119} \approx 260 \mathrm{~Hz}$ ) ppm. [ $\left.\alpha\right]_{\mathrm{D}}^{24}$ : -60.1 (c 0.10, Toluene).

(4b) Yield: 65\%. Anal. Calc. for $\mathrm{C}_{51} \mathrm{H}_{56} \mathrm{O}_{2} \mathrm{P}_{2} \mathrm{RuSn}$ (982.71): $\mathrm{C}$ 62.33; H, 5.74. Found: C: $62.55 ; \mathrm{H}: 5.80 \% .{ }^{1} \mathrm{H}$ NMR $\left(\mathrm{C}_{6} \mathrm{H}_{6}-d_{6}, 25^{\circ} \mathrm{C}\right)$ : $\delta 7.85-6.68(\mathrm{~m}, 30 \mathrm{H}, \mathrm{Ph}), 5.90$ (dd, ${ }^{3} \mathrm{~J}_{\mathrm{H}-\mathrm{P}}=11.2 \mathrm{~Hz},{ }^{3} \mathrm{~J}_{\mathrm{H}-\mathrm{H}}=7.9 \mathrm{~Hz}, 1 \mathrm{H}$, $\mathrm{CH} \mathrm{L}$ ), 4.98 (dd, $\left.{ }^{3} \mathrm{~J}_{\mathrm{H}-\mathrm{P}}=9.7 \mathrm{~Hz},{ }^{3} \mathrm{~J}_{\mathrm{H}-\mathrm{H}}=7.9 \mathrm{~Hz}, 1 \mathrm{H}, \mathrm{CH} \mathrm{L}\right), 1.40(\mathrm{~s}, 15 \mathrm{H}$, $\left.\mathrm{C}_{5} \mathrm{Me}_{5}\right), 0.30\left(\mathrm{~s},{ }^{2} \mathrm{~J}_{\mathrm{H}-119 \mathrm{Sn}} \approx 17 \mathrm{~Hz}, 9 \mathrm{H}, \mathrm{SnMe}_{3}\right) \mathrm{ppm} .{ }^{31} \mathrm{P}\left\{{ }^{1} \mathrm{H}\right\} \mathrm{NMR}$ $\left(\mathrm{C}_{6} \overline{\mathrm{H}}_{6}-d_{6}, 25^{\circ} \mathrm{C}\right) \delta: 172.2\left(\mathrm{~d},{ }^{2} \mathrm{JPP}=59.7 \mathrm{~Hz},{ }^{2} \mathrm{JP}_{\mathrm{P}-119 \mathrm{Sn}}=293.5 \mathrm{~Hz}\right.$, $\left.{ }^{2} \mathrm{JP}_{\mathrm{P}-\mathrm{Sn}}^{117}=277.2 \mathrm{~Hz}\right), 160.0\left(\mathrm{~d},{ }^{2} \mathrm{JPP}=59.7 \mathrm{~Hz},{ }^{2} \mathrm{JP}_{\mathrm{P}-\mathrm{Sn}}^{119}=293.8 \mathrm{~Hz},{ }^{2} \mathrm{JP}_{\mathrm{P}-}\right.$ $117 \mathrm{Sn}=282.5 \mathrm{~Hz}) \mathrm{ppm} .{ }^{13} \mathrm{C}\left\{{ }^{1} \mathrm{H}\right\} \mathrm{NMR}\left(\mathrm{C}_{6} \mathrm{H}_{6}-d_{6}, 25^{\circ} \mathrm{C}\right): \delta 147.1-127.3$ $(\mathrm{Ph}), 93.7\left(\mathrm{~s}, \mathrm{C}_{5} \mathrm{Me}_{5}\right), 85.4\left(\mathrm{~d},{ }^{2} \mathrm{~J}_{\mathrm{C}-\mathrm{P}}=10.1 \mathrm{~Hz}, \mathrm{CH} \mathrm{L}\right), 83.3$ (d, ${ }^{2} \mathrm{~J}_{\mathrm{C}}$ $\mathrm{p}=6.1 \mathrm{~Hz}, \underline{\mathrm{CH}} \mathrm{L}), 10.4\left(\mathrm{~s}, \mathrm{C}_{5} \mathrm{Me}_{5}\right), 1.4\left(\mathrm{~s}, \mathrm{JC}^{119} \mathrm{Sn}=3 \overline{7.2} \mathrm{~Hz}, \mathrm{SnMe}_{3}\right) \mathrm{ppm}$. ${ }^{119} \mathrm{Sn} \mathrm{NMR}\left(\mathrm{C}_{6} \mathrm{H}_{6}-d_{6}, 25^{\circ} \mathrm{C}\right): \delta 304.5\left(\mathrm{cdd},{ }^{2}{ }^{119}{ }_{\mathrm{Sn}}-\mathrm{P} \approx 292 \mathrm{~Hz}\right) \mathrm{ppm}$. $[\alpha]_{\mathrm{D}}^{24}: 163.8$ (c 0.20, Toluene).

(4c) Yield: 55\%. Anal. Calc. for: $\mathrm{C}_{50} \mathrm{H}_{48} \mathrm{O}_{2} \mathrm{P}_{2} \mathrm{RuSn}$ (962.64): C, 62.39; $\mathrm{H}, 5.03 \%$. Found: $\mathrm{C}, 62.44 ; \mathrm{H}, 5.20 \% .{ }^{1} \mathrm{H} \mathrm{NMR}\left(\mathrm{CH}_{2} \mathrm{Cl}_{2}-\mathrm{d}_{2}\right.$, $\left.25^{\circ} \mathrm{C}\right) \delta: 7.70-6.20\left(\mathrm{~m}, 34 \mathrm{H}, \mathrm{Ph}+\mathrm{H}_{5-7}\right.$ ind.), $5.71\left(\mathrm{~s}, 1 \mathrm{H}, \mathrm{H}_{2} \mathrm{C}_{9} \mathrm{H}_{7}\right)$, $5.05\left(\mathrm{~s}, 1 \mathrm{H}, \mathrm{H}_{1,3} \mathrm{C}_{9} \mathrm{H}_{7}\right), 5.01$ (dd, ${ }^{3} \mathrm{~J}_{\mathrm{H}-\mathrm{P}}=10.7 \mathrm{~Hz},{ }^{3} \mathrm{~J}_{\mathrm{H}-\mathrm{H}}=7.8 \mathrm{~Hz}, 1 \mathrm{H}$, $\mathrm{CH} \mathrm{L}), 4.64\left(\mathrm{~s}, 1 \mathrm{H}, \mathrm{H}_{1,3} \mathrm{C}_{9} \mathrm{H}_{7}\right), 4.40\left(\mathrm{dd},{ }^{3} \mathrm{~J}_{\mathrm{H}-\mathrm{P}}=10.5 \mathrm{~Hz},{ }^{3} \mathrm{~J}_{\mathrm{H}-\mathrm{H}}=7.8 \mathrm{~Hz}\right.$, $1 \overline{\mathrm{H}}, \mathrm{CH} \mathrm{L}),-0.09\left(\mathrm{~s},{ }^{2} \mathrm{JH}-\mathrm{Sn}=62.8 \mathrm{~Hz},{ }^{119} \mathrm{~J}-\mathrm{Sn}=19.04 \mathrm{~Hz}, 9 \mathrm{H}, \mathrm{CH}_{3}\right)$ ppm. ${ }^{31} \mathrm{P}\left\{{ }^{1} \mathrm{H}\right\}$ NMR $\left(\mathrm{CH}_{2} \mathrm{Cl}_{2}-d_{2}, 25^{\circ} \mathrm{C}\right) \delta$ : AB system, $\delta_{\mathrm{A}} 168.0$ $\left({ }^{2} \mathrm{JP}_{\mathrm{P}-\mathrm{Sn}}^{119}=290.0 \mathrm{~Hz},{ }^{2} \mathrm{JP}_{\mathrm{P}-\mathrm{Sn}}^{117}=276.1 \mathrm{~Hz}\right), \delta_{\mathrm{B}} 166.1\left({ }^{2} \mathrm{JP}_{\mathrm{P}-\mathrm{Sn}}^{119}=207.0 \mathrm{~Hz}\right.$, $\left.{ }^{2} \mathrm{~J}_{\mathrm{P}-\mathrm{Sn}}^{117}=199.2 \mathrm{~Hz}\right)\left({ }^{2} \mathrm{~J}_{\mathrm{AB}}=56.5 \mathrm{~Hz}\right) \mathrm{ppm} .{ }^{13} \mathrm{C}\left\{{ }^{1} \mathrm{H}\right\} \mathrm{NMR}\left(\mathrm{CH}_{2} \mathrm{Cl}_{2}-\mathrm{d}_{2}\right.$, $\left.25^{\circ} \mathrm{C}\right): \delta 149.8-120.5\left(\mathrm{Ph}+\mathrm{C}_{5-8} \mathrm{C}_{9} \mathrm{H}_{7}\right), 113.1$ (br s, $\left.\mathrm{C}_{4,9} \mathrm{C}_{9} \mathrm{H}_{7}\right), 106.4$ (br s, $\left.\mathrm{C}_{4,9} \mathrm{C}_{9} \mathrm{H}_{7}\right), 91.5$ (d, $\left.{ }^{2} \mathrm{~J}_{\mathrm{C}-\mathrm{P}}=4.3 \mathrm{~Hz}, \mathrm{C}_{2} \mathrm{C}_{9} \mathrm{H}_{7}\right), 84.8$ (d, ${ }^{2} \mathrm{JC}_{\mathrm{C}}$ $\mathrm{P}=9.3 \mathrm{~Hz}, \underline{\mathrm{CH} \mathrm{L}}), 83.1\left(\mathrm{~d},{ }^{2} \mathrm{~J}_{\mathrm{C}-\mathrm{P}}=6.6 \mathrm{~Hz}, \underline{\mathrm{CH} \mathrm{L}}\right), 70.7\left(\mathrm{~d},{ }^{2} \mathrm{~J}_{\mathrm{C}-\mathrm{P}}=9.8 \mathrm{~Hz}\right.$, $\left.\mathrm{C}_{1,3} \mathrm{C}_{9} \mathrm{H}_{7}\right), \overline{6} 7.3\left(\mathrm{~d},{ }^{2} \mathrm{~J}_{\mathrm{C}-\mathrm{P}}=10.6 \mathrm{~Hz}, \mathrm{C}_{1,3} \mathrm{C}_{9} \mathrm{H}_{7}\right),-2.0\left(\mathrm{~s}, \mathrm{JC}_{\mathrm{C}}^{119} \mathrm{Sn}=91.1 \mathrm{~Hz}\right.$, $\left.\mathrm{CH}_{3}\right)$ ppm. ${ }^{119} \mathrm{Sn}\left\{{ }^{1} \mathrm{H}\right\}$ NMR $\left(\mathrm{CH}_{2} \mathrm{Cl}_{2}-d_{2}, 25^{\circ} \mathrm{C}\right) \delta$ : ABM system $\left(\mathrm{M}={ }^{119} \mathrm{Sn}\right) 48.6\left({ }^{2} \mathrm{~J}_{\mathrm{MA}}=290.0 \mathrm{~Hz},{ }^{2} \mathrm{~J}_{\mathrm{MB}}=207.0 \mathrm{~Hz}\right)$ ppm. $[\alpha]_{\mathrm{D}}^{27}$ : 646.9 (c $0.23, \mathrm{CHCl}_{3}$ ).

\subsection{5. $\left[R u\left\{S n(C \equiv C P h)_{3}\right\}\left(C p^{\prime}\right) L\right]\left[C p^{\prime}=\eta^{5}-C_{5} H_{5}(\mathbf{5 a}), \eta^{5}-C_{5} M e_{5}(\mathbf{5 b})\right.$, $\left.\eta^{5}-\mathrm{C}_{9} \mathrm{H}_{7}(\mathbf{5 c})\right]$}

An excess of lithium phenylacetylide $(1.70 \mathrm{mmol}, 1.70 \mathrm{~mL}$ of a $1 \mathrm{M}$ THF solution) was added to a suspension of $0.17 \mathrm{mmol}$ of the corresponding trichlorostannyl complexes $\left[\mathrm{Ru}\left(\mathrm{SnCl}_{3}\right)(\mathrm{Cp}) \mathrm{L}\right](\mathbf{2 a - c})$ in $15 \mathrm{~mL}$ diethyl ether cooled to $-196^{\circ} \mathrm{C}$. The mixture was warmed to room temperature and stirred for $3 \mathrm{~h}$. The solvent was removed under vacuum, and the yellow residue was dissolved in toluene $(20 \mathrm{~mL})$ and filtered through celite ${ }^{\circledR}$. The solvent was removed under vacuum affording an oil that was treated with ethanol $(3 \mathrm{~mL})$. The yellow solid obtained was filtered, washed with ethanol $(2 \times 3 \mathrm{~mL})$ and dried under vacuum.

(5a) Yield: $65 \%$. Anal. Calc. for $\mathrm{C}_{67} \mathrm{H}_{52} \mathrm{O}_{2} \mathrm{P}_{2} \mathrm{RuSn}$ (1172.15): C, 68.59; H, 4.47. Found: C: 69.01; H: 4.52\%. FT-IR (ATR): $v_{\mathrm{C} \equiv \mathrm{C}} 2124$ (m) $\mathrm{cm}^{-1} .{ }^{\mathrm{H}} \mathrm{HMR}\left(\mathrm{CH}_{2} \mathrm{Cl}_{2}-\mathrm{d}_{2}, 25^{\circ} \mathrm{C}\right): \delta 7.62-6.48(\mathrm{~m}, 45 \mathrm{H}, \mathrm{Ph}), 6.01$ (dd, $\left.{ }^{3} \mathrm{JH}_{\mathrm{H}-\mathrm{P}}=11.6 \mathrm{~Hz},{ }^{3} \mathrm{~J}_{\mathrm{H}-\mathrm{H}}=8.2 \mathrm{~Hz}, 1 \mathrm{H}, \mathrm{CH} \mathrm{L}\right), 4.93$ (cdd, ${ }^{3} \mathrm{~J}_{\mathrm{H}-\mathrm{P}}={ }^{3} \mathrm{~J}_{\mathrm{H}-}$ $\mathrm{H}=7.9 \mathrm{~Hz}, 1 \mathrm{H}, \mathrm{CH} \mathrm{L}), 4.82\left(\mathrm{~s}, 5 \mathrm{H}, \mathrm{C}_{5} \mathrm{H}_{5}\right) \mathrm{ppm} .{ }^{31} \mathrm{P}\left\{{ }^{1} \mathrm{H}\right\} \mathrm{NMR}\left(\mathrm{CH}_{2} \mathrm{Cl}_{2}-\right.$ $\left.d_{2}, 25^{\circ} \mathrm{C}\right): \delta \mathrm{AB}, \bar{\delta}_{\mathrm{A}} 162.7, \delta_{\mathrm{B}} 161.0,{ }^{2} \mathrm{JAB}=59.0 \mathrm{~Hz} \mathrm{ppm}{ }^{13} \mathrm{C}\left\{{ }^{1} \mathrm{H}\right\} \mathrm{NMR}$ $\left(\mathrm{CH}_{2} \mathrm{Cl}_{2}-d_{2}, 25^{\circ} \mathrm{C}\right): \delta 148.9-125.4(\mathrm{Ph}), 107.5$ (s, $\mathrm{C}_{\beta}$ acetylide $), 100.7$ ( $\mathrm{s}, \mathrm{C}_{\alpha}$ acetylide), $85.6\left(\mathrm{~d},{ }^{2} \mathrm{~J}_{\mathrm{C}-\mathrm{P}}=9.1 \mathrm{~Hz}, \mathrm{CH} \mathrm{L}\right), 83.6\left(\mathrm{~s}, \mathrm{C}_{5} \mathrm{H}_{5}\right), 82.9$ (d, $\left.{ }^{2} \mathrm{JC}_{\mathrm{C}-\mathrm{P}}=5.2 \mathrm{~Hz}, \mathrm{CH} \mathrm{L}\right) \mathrm{ppm} .{ }^{119} \mathrm{Sn}\left\{{ }^{1} \mathrm{H}\right\} \mathrm{NMR}\left(\mathrm{CH}_{2} \mathrm{Cl}_{2}-\mathrm{d}_{2}, 25^{\circ} \mathrm{C}\right)$ : $\delta-248.5\left(\mathrm{cdd},{ }^{2} \mathrm{~J}_{\mathrm{Sn}-\mathrm{P}} \approx 380 \mathrm{~Hz}\right)$ ppm. [ $\left.\alpha\right]_{\mathrm{D}}^{27}: 245.4\left(\mathrm{c} 0.20, \mathrm{CHCl}_{3}\right)$.

(5b) Yield: $60 \%$. Anal. Calc. for $\mathrm{C}_{72} \mathrm{H}_{62} \mathrm{O}_{2} \mathrm{P}_{2} \mathrm{RuSn}$ (1240.19): C, 69.69; H, 5.04. Found: C, 70.01; H, 5.01\%. FT-IR (ATR): $v_{\mathrm{C} \equiv C} 2127$ (m) $\mathrm{cm}^{-1} .{ }_{1} \mathrm{H} \mathrm{NMR}\left(\mathrm{CH}_{2} \mathrm{Cl}_{2}-d_{2}, 25^{\circ} \mathrm{C}\right): \delta 7.81-6.35(\mathrm{~m}, 45 \mathrm{H}, \mathrm{Ph}), 5.99$ $\left(\mathrm{dd},{ }^{3} \mathrm{~J}_{\mathrm{H}-\mathrm{P}}=11.0 \mathrm{~Hz},{ }^{3} \mathrm{~J}_{\mathrm{H}-\mathrm{H}}=8.5 \mathrm{~Hz}, 1 \mathrm{H}, \mathrm{CH} \mathrm{L}\right), 4.72\left(\mathrm{cdd},{ }^{3} \mathrm{~J}_{\mathrm{H}-\mathrm{P}}={ }^{3} \mathrm{~J}_{\mathrm{H}-}\right.$ $\mathrm{H}=8.5 \mathrm{~Hz}, 1 \mathrm{H}, \mathrm{CH} \mathrm{L}), 1.54\left(\mathrm{~s}, 15 \mathrm{H}, \mathrm{C}_{5} \overline{\mathrm{Me}}_{5}\right) \mathrm{ppm} .{ }^{31} \mathrm{P}\left\{{ }^{1} \mathrm{H}\right\} \mathrm{NMR}$ $\left(\mathrm{CH}_{2} \mathrm{Cl}_{2}-d_{2}, \quad 25^{\circ} \mathrm{C}\right) \quad \delta: \quad \mathrm{AB}, \quad \delta_{\mathrm{A}} \quad 172.8 \quad\left({ }^{2} \mathrm{JP}_{\mathrm{P}-}^{119} \mathrm{Sn}=369.6 \mathrm{~Hz}\right.$, $\left.{ }^{2} \mathrm{JP}_{\mathrm{P}-\mathrm{Sn}}^{117}=351.1 \mathrm{~Hz}\right), \delta_{\mathrm{B}} 157.0\left({ }^{2} \mathrm{JP}_{\mathrm{P}-\mathrm{Sn}}^{119}=395.7 \mathrm{~Hz},{ }^{2} \mathrm{~J}_{\mathrm{P}-\mathrm{S}}^{117} \mathrm{Sn}=378.6 \mathrm{~Hz}\right)$, ${ }^{2} \mathrm{~J}_{\mathrm{AB}}=58.4 \mathrm{~Hz}$ ppm ${ }^{13} \mathrm{C}\left\{{ }^{1} \mathrm{H}\right\} \mathrm{NMR}\left(\mathrm{CH}_{2} \mathrm{Cl}_{2}-d_{2}, 25^{\circ} \mathrm{C}\right): \delta 146.4-125.7$ ( $\mathrm{Ph}), 107.2$ (s, $\mathrm{C}_{\beta}$ acetylide), 103.3 ( $\mathrm{s}, \mathrm{C}_{\alpha}$ acetylide), 93.1 (s, $\underline{C}_{5} \mathrm{Me}_{5}$ ), $85.0\left(\mathrm{~d},{ }^{2} \mathrm{~J}_{\mathrm{C}-\mathrm{P}}=10.0 \mathrm{~Hz}, \mathrm{CH} \mathrm{L}\right), 83.2\left(\mathrm{~d},{ }^{2} \mathrm{~J}_{\mathrm{C}-\mathrm{P}}=6.4 \mathrm{~Hz}, \mathrm{CH} \mathrm{L}\right), \overline{9} .92(\mathrm{~s}$, 
Table 5

Crystal data and structure refinement details for the $\mathbf{1 b}, \mathbf{2} \mathbf{b}$ and $\mathbf{2 c}$ compounds.

\begin{tabular}{|c|c|c|c|}
\hline & $1 \mathrm{~b}$ & $2 \mathrm{~b} \cdot 2 \mathrm{CHCl}_{3}$ & $2 \mathrm{c} \cdot \mathrm{CHCl}_{3}$ \\
\hline Empirical formula & $\mathrm{C}_{48} \mathrm{H}_{47} \mathrm{ClO}_{2} \mathrm{P}_{2} \mathrm{Ru}$ & $\mathrm{C}_{50} \mathrm{H}_{49} \mathrm{Cl}_{9} \mathrm{O}_{2} \mathrm{P}_{2} \mathrm{RuSn}$ & $\mathrm{C}_{48} \mathrm{H}_{40} \mathrm{Cl}_{6} \mathrm{O}_{2} \mathrm{P}_{2} \mathrm{RuSn}$ \\
\hline Formula weight & 854.32 & 1282.64 & 1143.20 \\
\hline Temperature (K) & $293(2)$ & $293(2)$ & $100(2)$ \\
\hline Wavelength $(\AA)$ & 0.71073 & 0.71073 & 0.71073 \\
\hline Crystal system & Monoclinic & Tetragonal & Orthorhombic \\
\hline Space group Unit cell dimensions & $\mathrm{P} 2_{1}$ & $\mathrm{P}_{4}$ & $P 2_{1} 2_{1} 2_{1}$ \\
\hline $\mathrm{a}(\AA)$ & $17.28(2)$ & $15.3139(5)$ & $13.3511(5)$ \\
\hline $\mathrm{b}(\AA)$ & $11.666(14)$ & $15.3139(5)$ & $18.2904(8)$ \\
\hline$c(\AA)$ & $20.74(3)$ & $23.1267(10)$ & $19.3411(7)$ \\
\hline$\beta$ & $102.21(3)^{\circ}$ & $90^{\circ}$ & $90^{\circ}$ \\
\hline Volume $\left(\AA^{3}\right)$ & $4086(9)$ & $5423.6(3)$ & $4723.0(3)$ \\
\hline Z & 4 & 4 & 4 \\
\hline Density (calculated) $\left(\mathrm{Mg} / \mathrm{m}^{3}\right)$ & 1.389 & 1.571 & 1.608 \\
\hline Absorption coefficient $\left(\mathrm{mm}^{-1}\right)$ & 0.566 & 1.279 & 1.294 \\
\hline$F(000)$ & 1768 & 2568 & 2280 \\
\hline Crystal size (mm) & $0.21 \times 0.09 \times 0.06$ & $0.18 \times 0.11 \times 0.09$ & $0.28 \times 0.07 \times 0.06$ \\
\hline$\theta$ range for data collection $\left({ }^{\circ}\right)$ & $2.24-26.47$ & $2.58-28.32$ & $2.38-28.33$ \\
\hline \multirow[t]{3}{*}{ Index ranges } & $-21 \leq \mathrm{h} \leq 19$ & $-15 \leq \mathrm{h} \leq 19$ & $-17 \leq \mathrm{h} \leq 17$ \\
\hline & $-14 \leq \mathrm{k} \leq 14$ & $-20 \leq \mathrm{k} \leq 13$ & $-24 \leq \mathrm{k} \leq 23$ \\
\hline & $-25 \leq 1 \leq 25$ & $-30 \leq 1 \leq 30$ & $-25 \leq 1 \leq 25$ \\
\hline Reflections collected & 57446 & 43324 & $4245 \overline{6}$ \\
\hline Independent reflections & $16732[\mathrm{R}$ (int) $=0.0446]$ & $13359[\mathrm{R}$ (int) $=0.0400]$ & $11711[\mathrm{R}$ (int) $=0.0347]$ \\
\hline Data completeness & 0.995 & 0.999 & 0.996 \\
\hline Abs. Correc. & Semi-empirical from equivalents & Semi-empirical from equivalents & Semi-empirical from equivalents \\
\hline Max. and min. transmission & 0.7454 and 0.5166 & 0.7457 and 0.6182 & 0.9229 and 0.7093 \\
\hline Refinement method & Full-matrix least-squares on F2 & Full-matrix least-squares on F2 & Full-matrix least-squares on F2 \\
\hline Data/restraints/parameters & $16732 / 1 / 960$ & $13359 / 1 / 591$ & $11711 / 0 / 541$ \\
\hline Goodness-of-fit on $\mathrm{F}^{2}$ & 0.686 & 1.022 & 1.033 \\
\hline \multirow[t]{2}{*}{ Final $R$ indices $[I>2 \sigma(I)]$} & $\mathrm{R}_{1}=0.0319$ & $\mathrm{R}_{1}=0.0399$ & $\mathrm{R}_{1}=0.0277$ \\
\hline & $\mathrm{wR}_{2}=0.0889$ & $\mathrm{wR}_{2}=0.0776$ & $\mathrm{wR}_{2}=0.0536$ \\
\hline \multirow[t]{2}{*}{$\mathrm{R}$ indices (all data) } & $\mathrm{R}_{1}=0.0378$ & $\mathrm{R}_{1}=0.0520$ & $\mathrm{R}_{1}=0.0333$ \\
\hline & $w R_{2}=0.0963$ & $\mathrm{wR}_{2}=0.0831$ & $\mathrm{wR}_{2}=0.0555$ \\
\hline Absolute structure parameter & $0.027(15)$ & $-0.030(16)$ & $-0.022(13)$ \\
\hline Largest diff. peak and hole, e. $\AA^{-3}$ & 0.588 and -0.965 & 1.105 and -1.142 & 0.630 and -0.590 \\
\hline
\end{tabular}

$\left.\mathrm{C}_{5} \mathrm{Me}_{5}\right)$ ppm. ${ }^{119} \mathrm{Sn}\left\{{ }^{1} \mathrm{H}\right\}$ NMR $\left(\mathrm{CH}_{2} \mathrm{Cl}_{2}-d_{2}, 25^{\circ} \mathrm{C}\right): \delta-233.2$ (dd, ${ }^{2}{ }^{119} \mathrm{Sn}-\mathrm{PA}=369.6 \mathrm{~Hz},{ }^{2}{ }^{119} \mathrm{Sn}-\mathrm{PB}=395.0 \mathrm{~Hz}$ ) ppm. [ $\left.\alpha\right]_{\mathrm{D}}^{27}: 134.5$ (c 0.12, $\left.\mathrm{CHCl}_{3}\right)$.

(5c) Yield: $70 \%$. Anal. Calc. for $\mathrm{C}_{71} \mathrm{H}_{54} \mathrm{O}_{2} \mathrm{P}_{2} \mathrm{RuSn}$ (1220.92): C, 69.85; H, 4.46. Found: C, 70.32; H, 4.21\%. FT-IR (ATR): $v_{\mathrm{C} \equiv \mathrm{C}} 2125$ (m) $\mathrm{cm}^{-1} .1 \mathrm{H}$ NMR $\left(\mathrm{CH}_{2} \mathrm{Cl}_{2}-d_{2}, 25^{\circ} \mathrm{C}\right) \delta: 7.51-6.21\left(\mathrm{~m}, 49 \mathrm{H}, \mathrm{Ph}+\mathrm{H}_{5-7}\right.$ $\left.\mathrm{C}_{9} \mathrm{H}_{7}\right), 5.86\left(\mathrm{~s}, 1 \mathrm{H}, \mathrm{H}_{2} \mathrm{C}_{9} \mathrm{H}_{7}\right), 5.72\left(\mathrm{dd},{ }^{3} \mathrm{~J}_{\mathrm{H}-\mathrm{P}}=11.4 \mathrm{~Hz},{ }^{3} \mathrm{~J}_{\mathrm{H}-\mathrm{H}}=8.0 \mathrm{~Hz}\right.$, $1 \mathrm{H}, \mathrm{CH} \mathrm{L}$ ), 5.06 (s, $\left.1 \mathrm{H}, \mathrm{H}_{1,3} \mathrm{C}_{9} \mathrm{H}_{7}\right), 5.03$ (s, $1 \mathrm{H}, \mathrm{H}_{1,3} \mathrm{C}_{9} \mathrm{H}_{7}$ ), 4.63 (cdd, $\left.{ }^{3} \mathrm{~J}_{\mathrm{H}-\mathrm{P}}={ }^{3} \mathrm{~J}_{\mathrm{H}-\mathrm{H}}=8.0 \mathrm{~Hz}, 1 \mathrm{H}, \mathrm{CH} \mathrm{L}\right) \mathrm{ppm} .{ }^{31} \mathrm{P}\left\{{ }^{1} \mathrm{H}\right\} \mathrm{NMR}\left(\mathrm{CH}_{2} \mathrm{Cl}_{2}-d_{2}\right.$, $\left.25^{\circ} \mathrm{C}\right): \delta \mathrm{AB}, \delta_{\mathrm{A}} 166.6\left({ }^{2} \mathrm{JP}_{\mathrm{P}}^{119} \mathrm{Sn}=409.0 \mathrm{~Hz},{ }^{2} \mathrm{JP}_{\mathrm{P}-\mathrm{Sn}}^{117}=392.0 \mathrm{~Hz}\right), \delta_{\mathrm{B}} 162.7$ $\left({ }^{2} \mathrm{JP}-\mathrm{Sn}=343.0 \mathrm{~Hz},{ }^{2} \mathrm{JP}_{\mathrm{P}-}^{117} \mathrm{Sn}=331.0 \mathrm{~Hz}\right)\left({ }^{2} \mathrm{~J}_{\mathrm{AB}}=52.8 \mathrm{~Hz}\right) \mathrm{ppm} .{ }^{13} \mathrm{C}\left\{{ }^{1} \mathrm{H}\right\}$ $\operatorname{NMR}\left(\mathrm{CH}_{2} \mathrm{Cl}_{2}-d_{2}, 25^{\circ} \mathrm{C}\right): \delta 148.3-122.5\left(\mathrm{Ph}+\mathrm{C}_{5-8} \mathrm{C}_{9} \mathrm{H}_{7}\right), 109.0(\mathrm{~s}$, $\left.\mathrm{C}_{4,9} \mathrm{C}_{9} \mathrm{H}_{7}\right), 107.2\left(\mathrm{~s}, \mathrm{C}_{\beta}\right.$ acetylide, $\left.\mathrm{J}_{\mathrm{C}-\mathrm{Sn}}^{119}=51.3 \mathrm{~Hz}\right), 105.2\left(\mathrm{~s}, \mathrm{C}_{4,9} \mathrm{C}_{9} \mathrm{H}_{7}\right)$, $99.6\left(\mathrm{~s}, \mathrm{C}_{\alpha}\right.$ acetylide, $\left.\mathrm{JC}_{\mathrm{C}-\mathrm{Sn}}^{119}=258.9 \mathrm{~Hz}\right), 92.7\left(\mathrm{~d},{ }^{2} \mathrm{JC}_{\mathrm{P}} \mathrm{P}=3.4 \mathrm{~Hz}, \mathrm{C}_{2}\right.$ $\left.\mathrm{C}_{9} \mathrm{H}_{7}\right), 85.4\left(\mathrm{~d},{ }^{2} \mathrm{~J}_{\mathrm{C}-\mathrm{P}}=9.5 \mathrm{~Hz}, \underline{\mathrm{CH}} \mathrm{L}\right), 83.0\left(\mathrm{~d},{ }^{2} \mathrm{~J}_{\mathrm{C}-\mathrm{P}}=6.0 \mathrm{~Hz}, \underline{\mathrm{CH} \mathrm{L}}\right), 71.2$ $\left(\mathrm{d},{ }^{2} \mathrm{~J}_{\mathrm{C}-\mathrm{P}}=5.8 \mathrm{~Hz}, \mathrm{C}_{1,3} \mathrm{C}_{9} \mathrm{H}_{7}\right), 69.7\left(\mathrm{~d},{ }^{2} \mathrm{~J}_{\mathrm{C}-\mathrm{P}}=6.8 \mathrm{~Hz}, \mathrm{C}_{1,3} \mathrm{C}_{9} \mathrm{H}_{7}\right) \mathrm{ppm}$. ${ }^{119} \mathrm{Sn}\left\{{ }^{1} \mathrm{H}\right\} \quad \mathrm{NMR} \quad\left(\mathrm{CH}_{2} \mathrm{Cl}_{2}-\mathrm{d}_{2}, \quad 25^{\circ} \mathrm{C}\right): \quad \delta \quad-267.0 \quad\left(\mathrm{dd},{ }^{2} \mathrm{~J}^{119} \mathrm{Sn}-\right.$ $\mathrm{PA}=409.0 \mathrm{~Hz},{ }^{2} \mathrm{~J}^{119} \mathrm{Sn}-\mathrm{PB}=343.0 \mathrm{~Hz}$ ) ppm. $[\alpha]_{\mathrm{D}}^{27}: 425.5$ (c 0.19 , $\mathrm{CHCl}_{3}$ ).

4.3.6. Crystal structure determination of $\left[\mathrm{RuCl}\left(\eta^{5}-\mathrm{C}_{5} \mathrm{Me} \mathrm{e}_{5}\right) L\right](\mathbf{1 b})$, $\left[\mathrm{Ru}\left(\mathrm{SnCl}_{3}\right)\left(\eta^{5}-\mathrm{C}_{5} \mathrm{Me}_{5}\right) \mathrm{L}\right](\mathbf{2} \boldsymbol{b})$, and $\left.\left[\mathrm{Ru}\left(\mathrm{SnCl}_{3}\right)\left(\eta^{5}-\mathrm{C}_{9} \mathrm{H}_{7}\right) \mathrm{L}\right](\mathbf{2} \mathbf{c})\right]$

Crystallographic data were collected on Bruker D8 Venture diffractometer at CACTI (Universidade de Vigo) with graphite monochromated Mo K $\alpha$ radiation $(\lambda=0.71073 \AA)$ and were corrected for Lorentz and polarization effects. APEX 3 software was used for collecting data frames, indexing reflections, and determining lattice parameters, SAINT [18] for integration of intensity of reflections and scaling, and SADABS [19] for empirical absorption correction. The crystallographic treatment of the compounds $\mathbf{1 b}, \mathbf{2 b}$ and 2c was performed with the SHELXL97 program [20]. The structures were solved by direct methods and refine by a fullmatrix-least-squares based of $\mathrm{F}^{2}$. Non-hydrogen atoms were refined with anisotropic displacement parameters. Hydrogen atoms were included in idealized positions and refined with isotropic displacement parameters. Details of crystal data and structural refinement are given in Table 5.

\subsection{Computational details}

DFT calculations were carried out with the Gaussian09 package [21]. X-Ray geometries were taken as starting points to perform DFT optimizations at the B3LYP/cc-pVDZ level. Heavy atoms, Ru and Sn, were described using the cc-pVDZ-PP basis set, which includes small-core relativistic pseudopotentials that account also for relativistic effects [9] Analytical vibrational frequency calculations were carried out to establish the minimum nature of each conformation. Later, NBO analysis [10] and calculation of Wiberg bond indices [11] were performed at the B3LYP6/cc-pVDZ (-PP) level.

\section{Acknowledgements}

Financial support from Xunta de Galicia (Spain) (research Project ED431D 2017/0) is gratefully acknowledged. We thank the Structural Determination Service of the Universidade de Vigo CACTI for X-ray diffraction measurements and the collections of NMR data.

\section{Appendix A. Supplementary data}

Supplementary data related to this article can be found at https://doi.org/10.1016/j.jorganchem.2018.08.017. 


\section{References}

[1] (a) X. Miao, A. Blokhin, A. Pasynskii, S. Nefedov, S.N. Osipov, T. Roisnel, C. Bruneau, P.H. Dixneuf, Organometallics 29 (2010) 5257-5262;

(b) M.P. Mingos, R.H. Crabtree (Eds.), Comprehensive Organometallic Chemistry, Elsevier, Amsterdam, 2007;

(c) W.R. Roper, L.J. Wright, Organometallics 25 (2006) 4704-4718;

(d) B. Eguillor, M. Esteruelas, M. Oliván, E. Oñate, Organometallics 24 (2005) 1428-1438;

(e) A.G. Davies, Organotin Chemistry, Wiley-VCH, Weinheim, Germany, 2004; (f) F.G.A. Stone, E.W. Abel, G. Wilkinson (Eds.), Comprehensive Organometallic Chemistry, Pergamon Press, New York, 1995;

(g) M.F. Lappert, R.S. Rowe, Coord. Chem. Rev. 100 (1990) 267-292;

(h) M.S. Holt, W.L. Wilson, J.H. Nelson, Chem. Rev. 89 (1989) 11-49.

[2] (a) M. Novák, M. Bouška, L. Dostál, M. Lutter, K. Jurkschat, J. Turek, F. De Proft, Z. Růžičková, R. Jambor, Eur. J. Inorg. Chem. (2017) 1292-1300;

(b) G. Albertin, S. Antoniutti, J. Castro, S. Da Lio, Organometallics 32 (2013) 3651-3661;

(c) G. Albertin, S. Antoniutti, J. Castro, Organometallics 29 (2010) 3808-3816; (d) G. Albertin, S. Antoniutti, S. García-Fontán, G. Zanardo, Organometallics 27 (2008) 2789-2794;

(e) G. Albertin, S. Antoniutti, A. Bacchi, G. Pelizzi, G. Zanardo, Organometallics 27 (2008) 4407-4418;

(f) G. Albertin, S. Antoniutti, J. Castro, S. García-Fontán, M. Noe, Dalton Trans. (2007) 5441-5452;

(g) H. Braunschweig, H. Bera, B. Geibel, R. Dörfler, D. Götz, F. Seeler, T. Kupfer, K. Radacki, Eur. J. Inorg. Chem. (2007) 3416-3424;

(h) M.M. Möhlen, C.E.F. Rickard, W.R. Roper, G.R. Whittell, L.J. Wright, Inorg. Chim. Acta. 360 (2007) 1287-1297;

(i) W.R. Roper, L.J. Wright, Organometallics 25 (2006) 4704-4718.

[3] (a) M.S. Winston, E.R. Batista, P. Yang, A.M. Tondreau, J.M. Boncella, Inorg. Chem. 55 (2016) 5534-5539.

[4] (a) P.A. Robles-Dutenhefner, E.M. Moura, G.J. Gama, H.G.L. Siebald, E.V. Gusevskaya, J. Mol. Catal. Chem. 164 (2000) 39-47;

(b) B.A.C. Silva, A.P. Guimaraes de Sousa, J.D. Ardinsson, H.G.L. Siebald, E. Moura, E.N. Santos, N.S. Mohallem, R. Montero Lago, Mater. Res. 6 (2003) $137-144$.

[5] (a) A. Fuerte, M. Iglesias, F. Sánchez, J. Organomet. Chem. 588 (1999) 186-194;

(b) V.I. Tararov, R. Kadyrov, T.H. Riermeier, J. Holz, A. Börner, Tetrahedron Asymmetry 10 (1999) 4009-4015;

(c) G. Zhu, X. Zhang, J. Org. Chem. 63 (1998) 3133-3136;

(d) R.K. Sharma, A.G. Samuelson, Tetrahedron Asymmetry 18 (2007) 2387-2393;

(e) R.K. Sharma, M. Nethaji, A.G. Samuelson, Tetrahedron Asymmetry 19 (2008) 655-663.

[6] P. Bergamini, V. Bertolasi, M. Cattabriga, V. Ferretti, U. Loprieno, N. Mantovani, L. Marvelli, Eur. J. Inorg. Chem. (2003) 918-925.

[7] M. Kawashima, R. Hirata, Jpn. Kokai Tokkyo Koho (1994). JP 06345789 A 19941220.

[8] (a) R.P. Nair, K. Tae Ho, B.J. Frost, Organometallics 28 (2009) 4681-4688;

(b) M.I. Bruce, B.G. Ellis, B.W. Skelton, A.H. White, Organometallics 22 (2003)
3184-3198;

(c) I. De los Ríos, M. Jimenez Tenorio, J. Padilla, M.C. Puerta, P. Valerga, J. Chem. Soc., Dalton Trans. (1996) 377-381;

(d) J.R. Torres-Lubián, M.E. Sánchez-Castro, P. Juárez-Saavedra, J. HernándezMartínez, B. Gordillo-Román, M.A. Paz-Sandoval, J. Organomet. Chem. 663 (2002) 127-133;

(e) S.A. Serron, L. Luo, E.D. Stevens, S.P. Nolan, Organometallics 15 (1996) 5209-5215;

(f) G. Consiglio, F. Morandini, G. Ciani, A. Sirone, M. Kretschmer, J. Am. Chem. Soc. 105 (1983) 1391-1392;

(g) E. Moura, H.G.L. Siebald, G.M. De Lima, Polyhedron 21 (2002) 2323-2331.

[9] (a) T.H. Dunning Jr., J. Chem. Phys. 90 (1989) 1007-1023;

(b) D.E. Woon, T.H. Dunning Jr., J. Chem. Phys. 98 (1993) 1358-1371;

(c) K.A. Peterson, J. Chem. Phys. 119 (2003) 11099-11112;

(d) K.A. Peterson, D. Figgen, M. Dolg, H. Stoll, J. Chem. Phys. 126 (2007), 124101-1 - 124101-12.

[10] (a) J.P. Foster, F. Weinhold, J. Am. Chem. Soc. 102 (1980) 7211-7218;

(b) F. Weinhold, J. Comput. Chem. 33 (2012) 2363-2379 (and references wherein);

(c) C.R. Landis, F. Weinhold, in: G. Frenking, S. Shaik (Eds.), The Chemical Bond: Fundamental Aspects of Chemical Bonding, Wiley-VCH, Weinheim, 2014.

[11] K.B. Wiberg, Tetrahedron 24 (1968) 1083-1096.

[12] A.E. Reed, R.B. Weinstock, F. Weinhold, J. Chem. Phys. 83 (1985) 735-746.

[13] (a) G. Chalasinski, M.M. Szczesniak, Chem. Rev. 100 (2000) 4227-4252; (b) N. Kobko, J.J. Dannenberg, J. Phys. Chem. 105 (2001) 1944-1950.

[14] D.D. Perrin, W.L.F. Armarego, Purification of Laboratory Chemicals, third ed. Butterworth/Heinemann, London/Oxford, 1998.

[15] M.I. Bruce, C. Hameister, A.G. Swincer, R.C. Wallis, Inorg. Synth. 21 (1982) 78.

[16] M.S. Chinn, D.M. Heinekey, J. Am. Chem. Soc. 112 (1990) 5166-5175.

[17] L.A. Oro, M.A. Ciriano, M. Campo, C. Foces Foces, F.H. Cano, J. Organomet. Chem. 289 (1985) 117-131.

[18] SAINT Version 6.01, Data Integration Software Package, Bruker Analytical XRay Systems Inc., Madison, Wisconsin, USA, 1997.

[19] G.M. Sheldrick, SADABS. A Computer Program for Absorption Corrections University of Göttingen, Germany, 1996.

[20] G.M. Sheldrick, Acta Crystallogr. A64 (2008) 112-122.

[21] M.J. Frisch, G.W. Trucks, H.B. Schlegel, G.E. Scuseria, M.A. Robb, J.R. Cheeseman, G. Scalmani, V. Barone, B. Mennucci, G.A. Petersson, H. Nakatsuji, M. Caricato, X. Li, H.P. Hratchian, A.F. Izmaylov, J. Bloino, G. Zheng J.L. Sonnenberg, M. Hada, M. Ehara, K. Toyota, R. Fukuda, J. Hase - Gawa, M. Ishida, T. Nakajima, Y. Honda, O. Kitao, H. Nakai, T. Vreven, J.A. Montgomery Jr., J.E. Peralta, F. Ogliaro, M. Bearpark, J.J. Heyd, E. Broth-ers, K.N. Kudin, V.N. Staroverov, R. Kobayashi, J. Normand, K. Raghava-Chari, A. Rendell, J.C. Burant, S.S. Iyengar, J. Tomasi, M. Cossi, Rega, J.M. Millam, M. Klene, J.E. Knox, J.B. Cross, V. Bakken, C. Adamo, J. Jaramillo, R. Gomperts, R.E. Stratmann, O. Yazyev, A.J. Austin, R. Cammi, C. Pomelli, J.W. Ochterski, R.L. Martin, K. Morokuma, V.G. Zakrzewski, G.A. Voth, P. Salvador, J.J. Dannenberg, S. Dapprich, A.D. Daniels, O. Farkas, J.B. Foresman, J.V. Ortiz, J. Cioslowski, V. Fox, Gaussian 09, Revision A01, Gaussian, Inc., Wallingford CT, USA, 2009. 